\title{
The Symbolic Meaning of Mosque Architecture as Adaptation to the Residential Environment, in the Social, Economic and Cultural Contexts in Lombok
}

\author{
Taufan Hidjaz $^{1}$, Nurtati Soewarno ${ }^{2}$, Detty Fitriany ${ }^{1}$ \\ ${ }^{1}$ Interior Design Department, Institut Teknologi Nasional, Bandung, Indonesia \\ ${ }^{2}$ Architecture Department, Institut Teknologi Nasional, Bandung, Indonesia
}

Email address:

htaufanhidjaz@yahoo.co.id (T. Hidjaz), nurtati@itenas.ac.id (N. Soewarno), detty_ft@itenas.ac.id (D. Fitriany)

To cite this article:

Taufan Hidjaz, Nurtati Soewarno, Detty Fitriany. The Symbolic Meaning of Mosque Architecture as Adaptation to the Residential Environment, in the Social, Economic and Cultural Contexts in Lombok. International Journal of Architecture, Arts and Applications. Vol. 5, No. 3, 2019, pp. 64-81. doi: 10.11648/j.ijaaa.20190503.11

Received: September 8, 2019; Accepted: September 22, 2019; Published: October 21, 2019

\begin{abstract}
The island of Lombok in Central Indonesia is native to Muslim Sasak ethnicity, but before 1400 there was still animism with a natural object-oriented housing environment as a symbol of 'the mother of all places'. After becoming Islam, it was adapted as 'the mother of waiting space' with a symbol of mosque architecture. The architecture of the mosque reflects the social, cultural and economic aspects of the people of Lombok. The large number of mosques shows that Islam is dominant in the lives of Sasak people. Its architecture in the early roofs was tile-roofed like a house, changed into a dome to show the identity of Islamic architecture. Intersubjectively the dome is accepted because it matches the shape of the food hood in Sasak culture. Many mosques adapt to high domes and towers, prominently in modest residential environments. This research is to understand the transformation that makes the number of mosques very large in Lombok. Using descriptive-analyticalqualitative methods based on environmental culture analyzes the symbolic meaning of mosque architecture in the Social, Economic and Sasak Cultural contexts.
\end{abstract}

Keywords: Mosque, Transformation, Cultural Adaptation, Lombok

\section{Introduction}

The architectural character reflects the identity of the community, and these character features result from the cultural patterns, symbols, and social events of the community, in addition to economic, political, ideological, historical, tradition, customary and community values [1]. Research on mosque architecture as part of the environmental culture in Lombok, is in line with the interest in developing rural communities, and what the city might learn from Sasak cultural wisdom in the villages. The vast majority of the population of Lombok is in the villages, as it is pointed out that almost half of the people are rural, the majority live in villages, somewhere in ninety-seven percent of the world's land mass defined as non-urban [2]. It is not only the ability of self-sufficiency in villages to be seen but the historical integration in its socio-economic potential that can connect rural areas in the spatial network of thematic tourism in
Lombok with the cultural background of residential clusters.

Villages in Lombok from the cluster residence of bale langgak are typically centered on the orientation of the mosque, which is inhabited by Sasak people from one extended family or 'sorohan'. Then it develops into the environment of the village community, and forms a cultural value system that binds its members in the social system of kinship. Hamlet and village environments make the mosque as the center or core, in the spatial structure that represents Sasak culture. The cultural space in Lombok is the natural space where the Sasak culture takes place, forming a structure of patterned relationships between community activities and the mosque. The formation of the structure of spatial relations when making various adaptations to changes that reach the guidelines for life in behavior. This adaptation places the mosque in the most important position as the center of housing in the perspective of the village community in Lombok. The mosque is indeed one of the most important 
types of buildings for any community, where Muslims gather for their prayers and social activities [3]. But the mosque in the Sasak residential environment not only reflects as an artifact of the functional building of a place of worship, but the whole perspective and values that are dominant bind to the community. Therefore, in addition to the physical nature, the mosque for the Sasak cluster of spiritual values has a spiritual value which is a concrete illustration of Sasak culture. Therefore the number of mosques is proportional to the number of hamlets in Lombok so that it is called the Thousand Islands Mosque.

Lombok hamlets form cluster occupancy patterns not linearly on the side of the highway with mosque architecture as a landmark, depicting the culture of the community which has a unique value system regarding space. Urban spatial structure is also affected by the same pattern, which is centered on the mosque, so that since Lombok since 1970 it has been dubbed 'the island with thousands of mosques', although the number now reaches 9,000 mosques. The residential space in the villages of Lombok is not attached to the main road transportation lane, because it is more concerned with the position near the mosque than economic activity. The question of this research is how the transformation process of Sasak residential space in Lombok which was previously objectoriented in landscapes such as mountains, springs, large trees and then became mosque artifacts oriented.

Then what is the symbolic meaning of the mosque's architecture and interior with a central and monumental position in the relatively simple residential neighborhoods of hamlets in Lombok. The specific purpose of this research is to understand the meaning of mosque architecture as the center of the residential space environment of the cluster of traditional family houses of the Sasak people called: bale langgak, so that its presence is dominant in a simple hamlet environment. This study analyzes the process of transformation and adaptation of symbolic forms in the social, cultural and economic contexts of the Sasak people, as well as their possibilities to support "Muslim Friendly" Lombok tourism.

\section{Methodology}

This research uses descriptive-analytical-qualitative method based on environmental culture approach by considering cultural phenomena in the field of observation as the focus of research. Mosques that are considered to represent research problems are documented as objects of analysis, to illustrate the symbolic meaning in the process of cultural transformation of its originators. The study of the meaning of mosque artifacts has a lot of relationships with other cultural elements, hence it begins by questioning how the existence of several thousand mosques in housing clusters on the island of Lombok, how their orientation community space, how cosmology and values form residential patterns. Observations were made by identifying a number of mosques in the Sasak traditional residential space environment, looking at the structure of spatial relationships that were formed and binding each other between community activities and the housing environment.
Then analyze the factors that influence the architecture of the mosque and its central position in the housing cluster. This research really needs to understand the relationship between the concept of cultural space from Sasak language expressions and related terms whose implementation is manifested in cultural artifacts and housing patterns.

\section{Discussion}

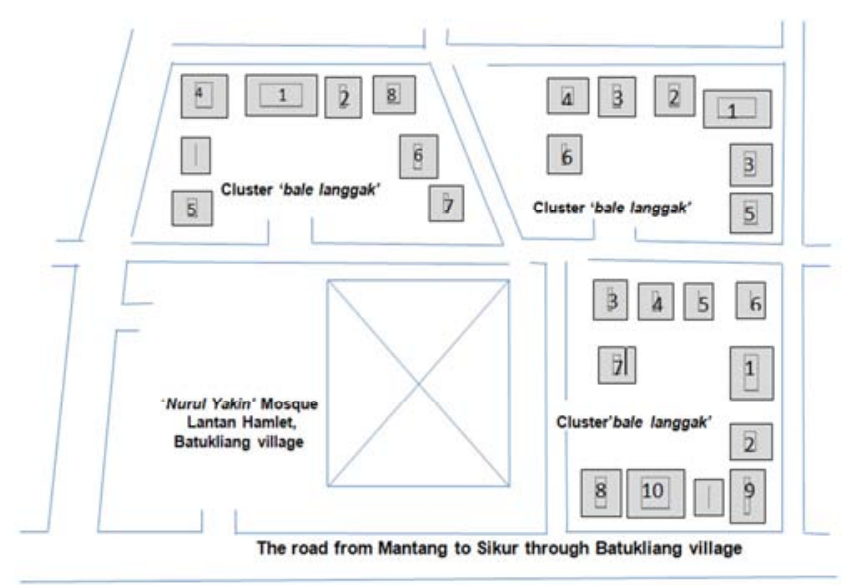

Figure 1. 'bale langgak' cluster in Lantan hamlet, Batukliang village, which contains: 1 parent's house, 2 gazebos for receiving guests called berugaq, 3 rice granaries where rice is stored, 4 children's homes, 5 children's homes, 6 children's homes.

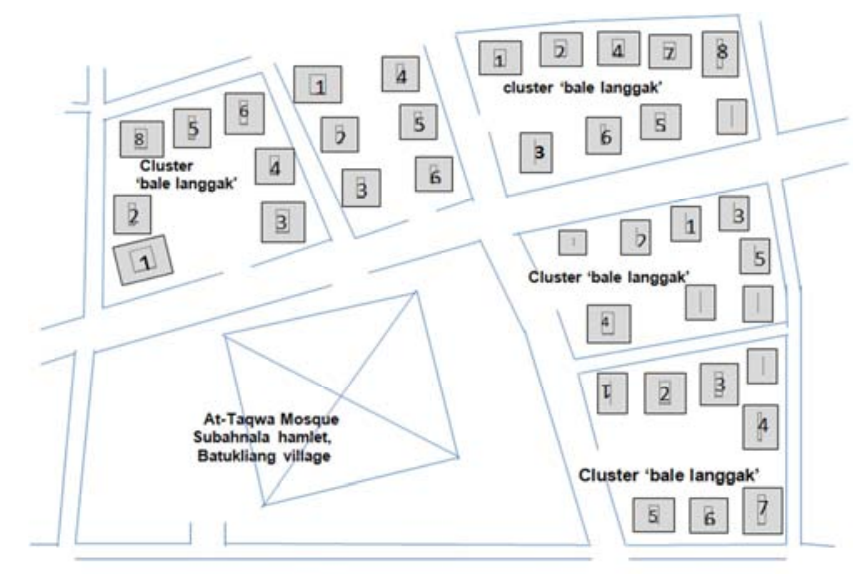

Figure 2. 'bale langgak' cluster in Subahnala hamlet, Batukliang village, which contains: 1 parent's house, 2 gazebos for receiving guests called berugaq, 3 rice granaries where rice is stored, 4 children's homes, 5 children's homes, 6 children's homes.

The mosque is a multidimensional Islamic architecture embodying the message of Islam. Both facilitate the realization of Muslims about the purpose of Islam and its divine principles on earth and promote the lifestyle produced by these philosophies and principles. The point in Islamic architecture lies its function with all its dimensions: corporeal, cerebral and spiritual. The shape also plays an important role, but to complement and enhance functions [4]. Once the importance of the mosque for the people of Lombok is described as a determination that the first procedure for building a residential environment is to build the mosque first. So it can be said that 
the mosque is the mother (ineun) of all residential spaces, because it has become an orientation since the beginning of the residential environment. Therefore the pattern formed later in the residential environment is a cluster model that surrounds the mosque's position.

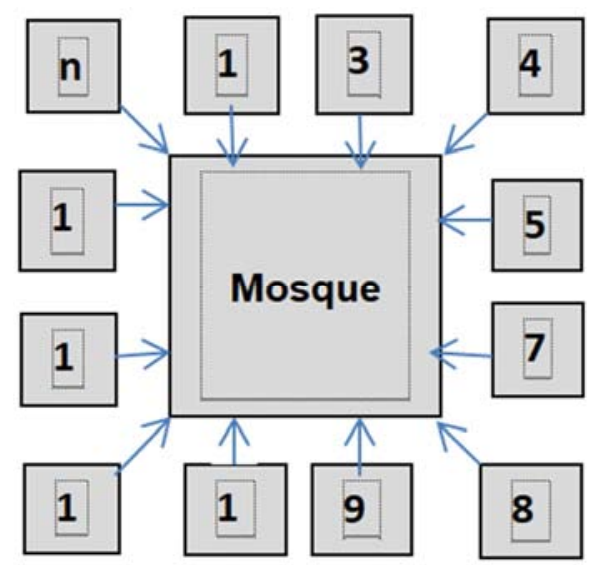

Figure 3. The activity space structure is formed from the Behavior Settings between the Bale Langgak family cluster and mosque, is the strongest activity space structure. 1, 2, 3, 4, 5, 6, 7. and so on is a bale langgak or cluster housing for large families of hamlet residents who are also tied to the mosque.

A number of locality characteristics in the mosque mark the mosque's architectural style and are always present binding it with dominant elements which then become a symbolic unity in appearance [5]. The dominant elements include: dome, tower, mihrab in a position towards Mecca, and pulpit. These elements are referred to as symbols that mark the existence of the mosque building. But the hallmarks of the mosque are not just showing monumental art done in the most sacramental manner, but also a symbol of religious zeal and the total sacred obligation of Muslims [6].

The sustainability of hamlets and villages in Lombok is closely related to the existence of the mosque. Each hamlet has its own mosque for daily prayer by residents of the hamlet, so that the adjacent hamlet has a mosque also next to each other so that on Friday prayers that require many worshipers, the Friday prayer schedule will alternate. The development of the mosque in Lombok is not only a place of prayer, but its form displays the symbolic meaning of the social, cultural and worldview of Sasak people. Because it is a product of local conditions related to the intellectual foundation of the Islamic faith. Islamic beliefs are the main aspects directing the mosque's architectural design, reflected in their outward form as a clear ideological reflection of the cultural, economic and social aspects of society.

\section{The Symbolic Meaning of the Mosque as the Mother of Waiting Space in Lombok}

The mosque became part of the worldview transformation of the old Sasak people or Sasak Lebung who were still animistic, then all of them turned into Islam. The orientation of the residential space of the Old Sasak community uses markers of natural objects that are important such as springs, mountains or large trees in each village as 'the mother of place'. Then after becoming Islamic everything was changed to 'the mother of waiting space' the markers were mosque artifacts. This causes every small village to have a mosque so that there are very many in Lombok

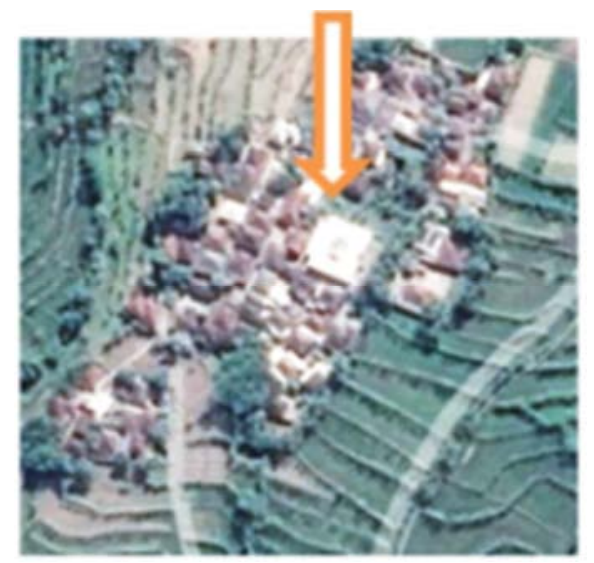

Figure 4. The position of the mosque in the village of Rumbuk, Sakra subdistrict, East Lombok Regency, two mosques in a hamlet which are adjacent, downloaded from Google maps on 21 June 2019 and processed.

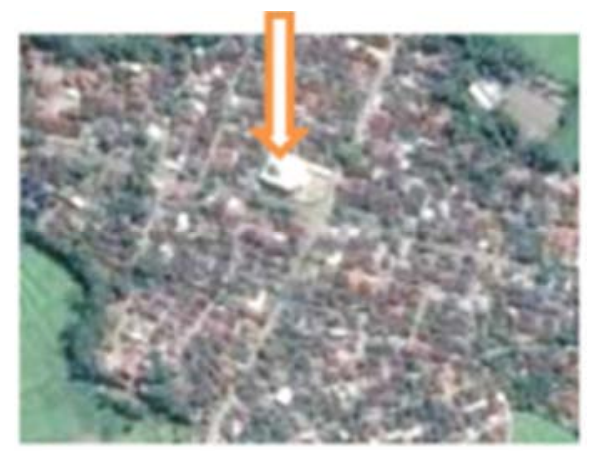

Figure 5. The position of the mosque in Montong Village, Central Lombok Regency is in the position as the core of a relatively large cluster of hamlet environments, downloaded from Google maps on 21 June 2019 and processed.

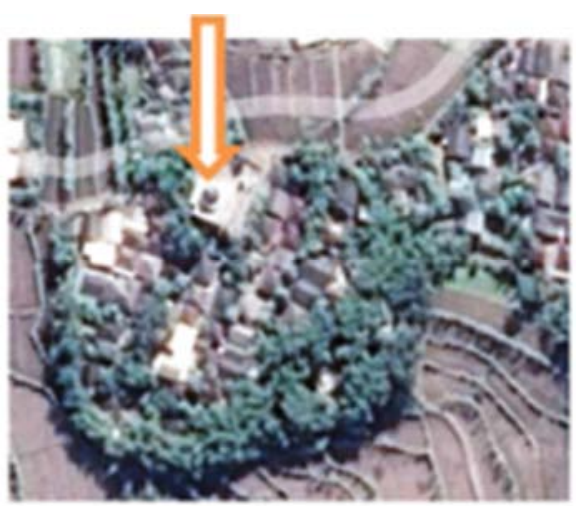

Figure 6. The Position of Jantuk hamlet mosque in Terara village, East Lombok district, downloaded from Google Maps on 21 June 2019 and processed. 


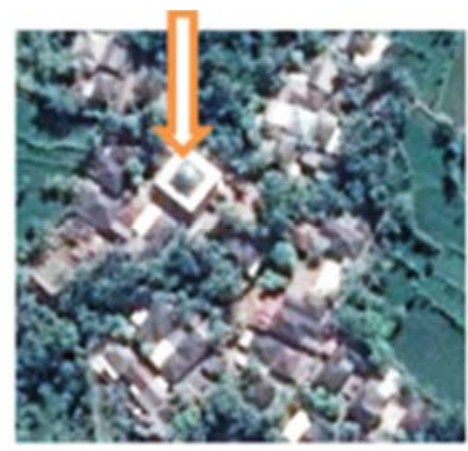

Figure 7. The position of the mosque of Durian Village, Janapria subdistrict, central Lombok District, downloaded from Google maps on 21 June 2019 and processed.

The four types of mosque positions in the village and hamlet residential areas represent thousands of Lombok mosques as 'the mother of waiting space' and the center of residential space orientation. There is no residential space without a mosque, because the people need orientation and a place to do joint prayers which must be done every day. The mosque is also an adaptation in the transformation of the worldview of the old Sasak community into a new Sasak community that is Islamic. This adaptation is a path of transformation that makes mosque artifacts very important for each residential space in Lombok, and in the context of society it becomes a representation of Sasak culture.

At the beginning of its history the old Sasak community called Sasak Lebung held to a mythic-animism cultural pattern that was very dependent on the surrounding environment. They in the formation of cosmology in the natural environment create a hierarchy for spatial orientation at the village level, hamlet, cluster 'bale langgak', on natural objects. The cosmology of Sasak Lebung has a spatial value and orientation aimed at mount Rinjani.



Figure 8. Sasak residential space pattern before Islam refers to the center of natural resources namely Mount Rinjani. Ineun Tetaok or the mother of place and Kemali or Water Spring are the closest to Mount Rinjani. If the occupancy space is to the south of Rinjani, then the position of 'the mother of place' or ineun tetaok is in the north of the residential space, if there is to the west, then the position of ineun tetaok is to the east of the occupancy space, and vice versa.
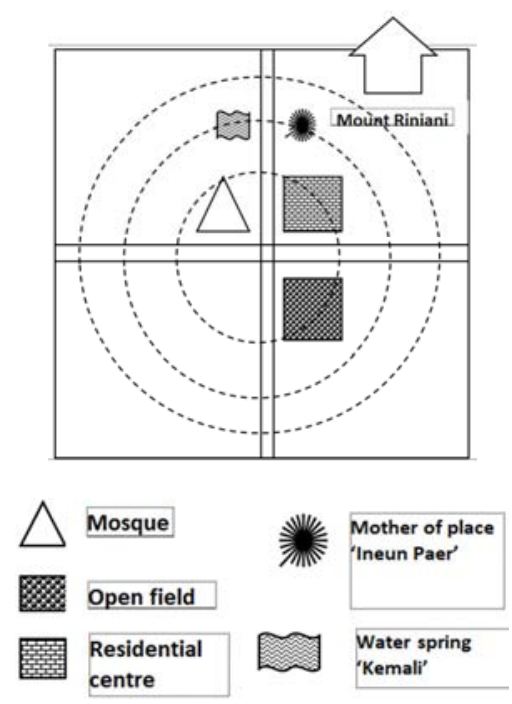

Figure 9. Residential pattern after Islam refers to the position of the mosque replacing the "the Mother of Place" position as the orientation of activities and the "the Mother of Waiting Space" symbol. The position of the mosque to the west of the dwelling, but when the village environment develops, the dwelling surrounds the position of the mosque.

The placement of residential space refers to the center of natural resources, namely Mount Rinjani. 'the mother of place' or ineun tetaok and water spring called kemali are the closest to mount Rinjani. If the residential space is to the south of Rinjani, the position of the mother of place is to the north of the residential space, if there is to the west, the position is to the east of the residential environment, and vice versa.

The influence of Islam entered Lombok through the arrival of its carriers from Java, and also from interactions with Islamic carriers from Sulawesi. The influence of Islam was very revolutionary towards the awareness of the Sasak people who had been animist. Residential spaces that were previously oriented to 'the Mother of Place' or Ineun Tetaok then transformed into a concept of space in the world of waiting called Paer which is oriented towards Islamic ideological insight based on the concept of life that is temporary before death. The cultural pattern of the Sasak community was previously mythic-animism which was confined by nature, then transformed into a religious-based mythic-religious Islam. Namely rely entirely on the power of God who rules over nature.

This comprehensive transformation in Sasak society is a change in intersubjective awareness and collectively influences the concept of their residential space from 'the mother of all place' to 'the mother of waiting space' before leading to death. After Sasak became a Muslim, cosmology oriented to mount Rinjani was adapted. The concept of place or tetaok becomes the waiting space and is called paer, which is in the Kawi-Javanese dictionary CF Winter. Sr. \& R. Ngabehi Ranggawarsita, the term paer comes from pahera pangentosan or waiting and pahyaran panggenan or place of residence. The meaning is a place to stay while waiting in the world of existence for a while before heading to 'eternal life' [7]. Adaptation of the concept of space after Islam is done by 
changing the rationale and understanding of ineun tetaok or the mother of place to become ineun paer or the mother of waiting space in the world of existence refers to the Islamic teaching that space in this world is a temporary place of waiting before continuing the journey in life after death. Therefore, mosque artifacts have symbolic meanings as markers of life space moving towards space travel after death

Islam is the basis of worldview for Sasak people so that the impact of all dwellings in Lombok is mosque-oriented as ineun paer. The concept of natural place and space as a temporary waiting facility and oriented to eternal life after death, the mosque is used as a marker and 'the mother of waiting space' or Ineun Paer as a substitute for 'the mother of place' or ineun tetaok which is derived from the concept animism. The implementation of this transformation resulted in a hierarchy of space in its broadness, starting from the village, hamlet, and bale langgak clusters, all of which were oriented towards the mosque's position. Ulama or religious leader in Islam become role models because they are individuals who spread awareness of religiosity from the main source for life in the period of waiting before heading for the aftermath.

The mosque is very important for the Sasak community space, as a marker to be recognized or identified so that in every village there will be a magnificent mosque that exceeds the surrounding residential buildings. Even in several locations, one village has two or three large mosques. Possibly because the activity accommodated included a large number of participants and was accompanied by the ability to raise funds for sufficient development, so the mosque was very easily seen from the edges of the village due to the high dimension of the dome roof and its tower.

The mosque is a place of worship, orientation, and symbols for all rural residential spaces, so that it is the most important building for all communities in the hamlet and villages. The largest and grandest building mosque in every village, so that the tower and dome of the mosque become a landmark for space and a village marker. Magnificent mosques that were built at a cost that was certainly not the least symbolized the success of villagers managing their fields and gardens. All villagers feel they have an obligation to contribute to the needs of the mosque construction. Therefore, every village in Lombok built a magnificent mosque as a space orientation and value for the spiritual life of their community, as well as symbolically grateful for their success in managing the rice fields in the village. the number of villages in the whole island of Lombok is 518 with a total of 3,575 large mosques and 4,918 small mosques, then in Mataram city there are 192 large mosques and 266 small mosques [8].

Table 1. The number of mosques on the island of Lombok.

\begin{tabular}{lllll}
\hline Regency / City & sub-district & village & The Great Mosque & Small Mosque \\
\hline Mataram City & 6 & & 192 & 266 \\
West Lombok Regency & & 119 & 695 & 701 \\
North Lombok Regency & 33 & 291 & 224 \\
Central Lombok Regency & 127 & 1.244 & 1.951 \\
East Lombok Regency & & 239 & 1.345 & 2.042 \\
Total & 518 & 3.767 & 5.184 \\
\hline
\end{tabular}

(Data from the Village Empowerment, Population and Civil Registry Office of NTB 2017)

In 518 villages across Lombok, there are nearly 9,000 mosques, most of which have a domed model and a tower to express their identity as 'the mother of waiting space' and residential orientation. Mosques that do not use the form of a domed model of the dome roof are only a small part of the old mosque in northern Lombok. The shape of the dome roof adjusts to something close to the elements of the original Sasak culture so that it can be accepted quickly and is considered suitable. The dome roof of the mosque which is adjusted as a form of tebolak or traditional food covering means symbolic as a protector of sustenance and all prosperity that the community strives for is due to God's love. Grateful for that it was stated by the people of Lombok by coming to the domed-roofed mosque of the domed model to worship God while living in this waiting space or paer. The azan tower that rises to the top and is easily visible from a distance means symbolic that the mosque is sturdy as the center of spatial orientation and continues to call the call to prayer.

Old mosques that were built before the 1970s still use the form of roofs made of tile material are still widely available in northern Lombok, but mosques built after the 1970s became prevalent using the shape of dome roofs and tall towers which number one or more even there were mosques five-legged. The first mosque in Lombok that was built using the dome roof is the At-Taqwa mosque in Mataram, which has a dome-shaped ball. But the dome model such as the AtTaqwa Grand Mosque did not continue to be followed by the others because the people of Lombok had not yet found their assimilation with local cultural elements to be accepted by intersubjectivity. Then the technological development of large-spaced dome structures was able to form assimilation with cultural artifact models from "tebolak" or traditional food hoods, so that the Sasak people found their references to adapt the mosque's architectural form. The ideas of structure, use of materials, functional and aesthetic considerations play a role in realizing the expression of mosque architecture. Also about the use of materials and aesthetics that depend on assimilation with technology. Then many large mosques with the shape of the dome and tower tower that turned towering became a symbol of the success of the village community, a symbol of joint results of economic activities carried out by 
the community. By having the same reference from tebolak cultural artifacts that are familiar with their daily lives, the Sasak people feel comfortable accepting it as a model of the roof of the mosque that is closer to Islamic architecture.

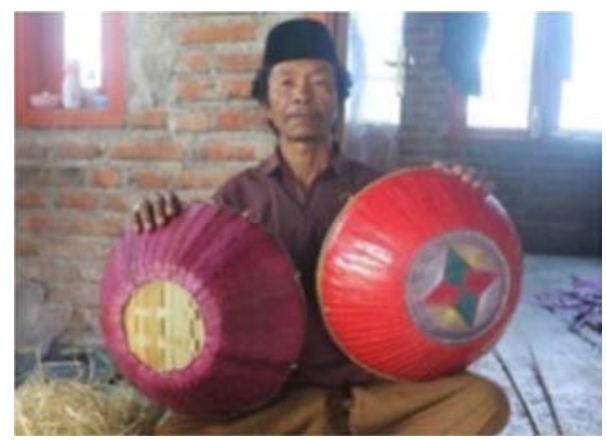

Figure 10. Traditional Sasak craftsman in the village of Lenek in East Lombok district showing the results of his work that has been completed and is still in process.

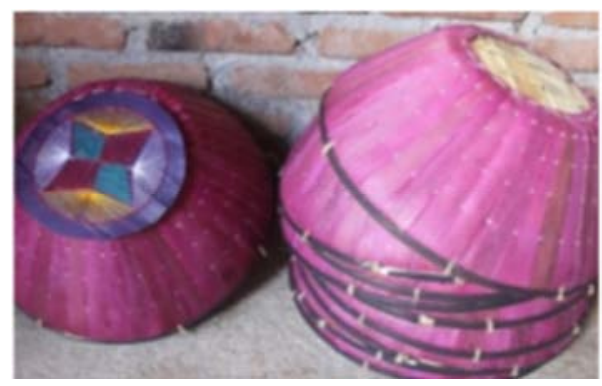

Figure 11. Tebolak that has been completed and the new Tebolak that was formed before being given ornamentation.

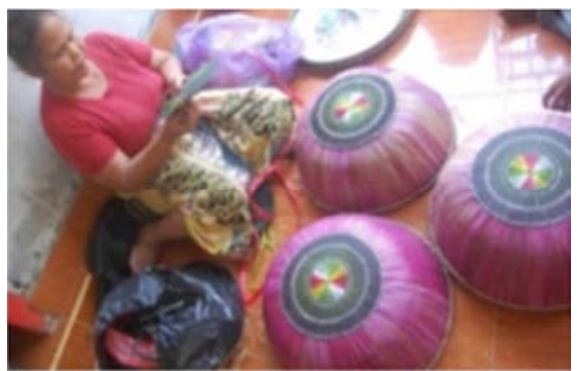

Figure 12. Traditional Sasak female craftsman in Sasak in the village of Pujut, Central Lombok, showing the process of sewing the rainbow threads at the peak circle in Tebolak.



Figure 13. Tebolak which has been finished with the top ornamentation and color finishing in several ornamental creations that have been developed in the villages of Kopang and Selong.

\section{Adaptation of the Dome Model with}

\section{Corresponding "Tebolak" Cultural Artifacts}

According to NTB Population and Civil Registry Office data, an estimated 7,000 mosques out of 9,000 mosques across Lombok now use the model of the roof of the domeshaped dome. Why did the Sasak people adapt the form of the domed dome to leave the roofed mosque architecture? Possibly because the shape of the roof is similar to a residential house and is a relic of Sasak Lebung which is animistic like an ancient mosque in the village of Bayan. By using the dome, the mosque is strived to be different from other buildings and contains familiar cultural elements such as tebolak. Islamic architecture has no rules and standardized forms, there are no restrictions on the pattern of its application in countries that embrace Islam. However, Islamic content is very easily recognized and recognized because it is made for building characters with different identities [9].

Tebolak or food coverings are cultural artifacts that are traditionally used in many villages in Lombok at a joint dinner or begibung every Eid day. The village community separately women and men after Eid prayer from their respective houses brought food offerings, on a $60 \mathrm{~cm}$ diameter round tray with a covering of woven leaf pandanus. These food trays are brought to a field to be first symbolically handed over to the village head and village elders then to be served at random exchanges. Tebolak becomes an important part of the tradition of serving food from the cluster of family dwellings or bale langgak to be exchanged by fellow villagers and guests outside the village when celebrating Eid.

Tebolak is also used when the villagers in Lombok commemorate the Prophet's Birthday, and a meal program after the Ramadhan tarawih prayer alternately submits to the mosque under tebolak as the closing ceremony. It can even be ascertained that every house in rural Lombok must save a lot of rice to cover a house dish, because it is familiar with the cultural activities of the Sasak people.

Tebolak then became a form of mosque architecture adaptation since the 1970s. The possibility of a community's phenomenological-collective corresponds to the intersubjective will of the cultural artifacts that is the cause. The people of Lombok see the suitability of the shape of the dome roof produced by new materials and technology with the form of cultural artifacts tebolak from the Sasak tradition. The dome roof model in the mosque did come from outside cultures and when this dome technology entered Lombok, there was intersubjectivity conformity to the symbolic form. Namely between the roof of the dome of the house of God with cultural artifacts tebolak as a protector of the blessing of the sustenance of the Sasak people from Allah in Lombok. The position of the form of tebolak on the mosque building symbolically states that the intersubjectivity of gratitude is most appropriate to be realized together in the mosque through worship activities in the mosque. This conformity is what makes the dome architecture model quickly accepted 
and adapted in almost all Sasak community mosques, because it is intersubjectively compatible so that it does not become controversial in the community.

The perspective of understanding the intersubjectivity around the object makes the success of the Sasak people accept the dome model replacing the old model in the mosque, built through information of religious leader or ulama so that this understanding encourages the will to achieve the same collective goal. The Lombok community has the same information about tebolak because it is familiar as its cultural artifacts and obtains the same information about mosques from ulama, this is a strong capital to form the same intersubjectivity in the dome of the mosque when it will adapt so that it does not become controversial.

The intersubjectivity incompatibility in the object in the first step becomes unsuccessful in the aspect of function, although in the aspect of novelty and the sensation of different forms from other mosques can be considered successful. Subjectivity becomes the beginning of the process of conformity in the next step which is identifying the environmental problems of the object of the mosque and its future goals. Only then will the subjective interpretations of the parties concerning the object of the same mosque be interpreted in the same manner by those who plan their realization. The next step is to look at the problems faced by the previous mosque, which are irrelevant must be reinterpreted in order to achieve new and different things but in the context of the same intersubjectivity.

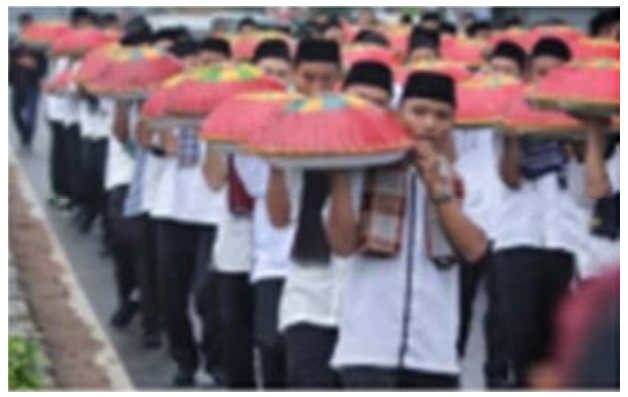

Figure 14. A procession of male group processions from Pujut village, Central Lombok carrying a traditional food tray covered by Tebolak to the arena in front of the village hall building for tray exchanges among residents, coordinated by the village head and traditional leaders. The size of the food tray is usually $60 \mathrm{~cm}$ in diameter so that the amount of food in it is almost the same.

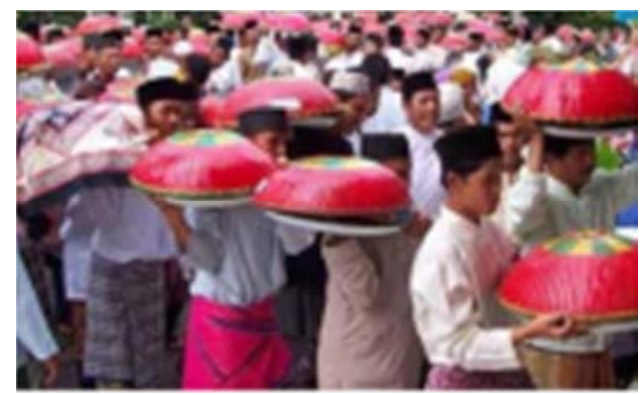

Figure 15. A procession of male group from Rumbuk village, East Lombok district on Eid al-Fitr carrying a traditional food tray covered by Tebolak to the food exchange arena in front of the village mosque, led by the village head and traditional leaders.

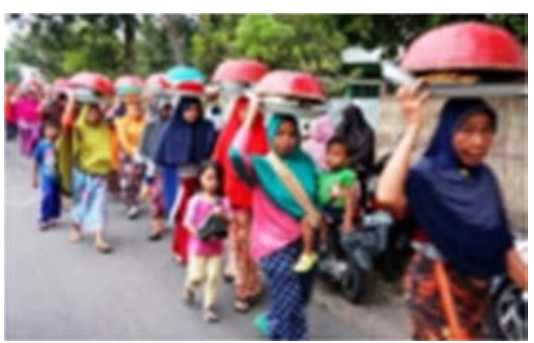

Figure 16. Procession of groups of women from Janapria village, Central Lombok district on Eid al-Fitr, carrying traditional food trays closed by Tebolak to the food exchange arena with villagers led by village heads and traditional leaders.

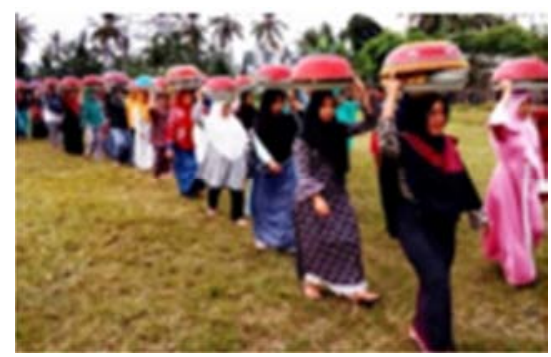

Figure 17. A group of women on Eid al-Fitr brought a traditional food tray closed Tebolak to the front office of the Pancor village office in East Lombok district as an arena of food exchange with fellow citizens led by the village head and traditional leaders.

\section{The Symbolic Meaning of Minarets in Lombok}

The mosque tower is just a building that is used to air a azan or call to prayer, but in the Hubbul Wathon mosque the Islamic Center complex of Mataram tower is 5 , one of which is an elevator to take visitors to a height of 99 meters to see the view of the city of Mataram. In most of the Lombok mosques the tower is integrated with the main building of the mosque, but many mosque towers are located separately from the main building. The minarets did not exist during the time of the Prophet and the Khulafaurrasyidin between 632661 [10], the Quba mosque that was first built by the Prophet Muhammad in Medina did not have a tower, only after 41 years the Prophet's death tower first stood beside the mosque building [11].

The Lombok mosques which are roofed in dome models all use a tower, and the end of the tower is fitted with the same dome model with a small circle diameter so that the end of the tower is always a repetition of the dome shape. The minaret is a high linear building architecture so the shape is straight to adjust the gravitational direction of the earth which is structurally the strongest and safest. The height of the tower shows the straightness of the linear structure of far vision, in addition to the ability of the height of the tower to spread the sound of the azan or call to prayer. Straight is an ideological meaning from the name of the Sasak community where the island of Lombok lives, which in Sasak is originally called lomboq meaning straight. More and more tower buildings whose form is straight and legible dominates the environment, symbolically there is a meaning that is 
easily accepted by the intersubjectivity of the Sasak people in Lombok, in accordance with the name Lomboq is straightness. provide compatibility when integrated with the form of tebolak on the dome on the roof of the mosque. The presence of the azan tower which is straight according to the meaning of the name of the island of Lombok. Lomboq in Sasak is straight, and forms such as the swaying of food protectors on the dome of the mosque building makes it a building full of symbolic meaning. Therefore the mosque building as a 'House of God' with its dome and linear tower becomes more solid the 'mother of waiting space' or ineun paer in each residential area of the Sasak community. So many symbolic meanings are inherent in the architecture of the mosque, so its presence in each residential area of the Sasak community is needed in almost 9000 hamlets in Lombok.

The appearance of the mosque qualitatively has a symbolic meaning for the success of each community's residential environment to organize togetherness in religious intersubjectivity. Although the actual quality of the appearance of the mosque is largely determined by the ability of the quantity of financing. This is correlated with the success of the community in managing agricultural businesses that are a source of income in each hamlet environment, or from other non-agricultural activities. Some villages show this, such as Sukarbela, the village that manages pearl crafts, in the village of Banyumulek managing traditional pottery handicrafts, Sukarare village manages woven fabric crafts. The successes of the village like this will be symbolized by the quality of the architecture of the mosque in terms of the grandeur of the use of building materials and the presence of the dome and the minaret of the mosque. The mosque provides a spatial solution as concluded to Muslim immigrant residents in Berlin and London who join and become the subject of ongoing discourse on national ownership [12]. In such cases, mosque spaces are used to support specific visions of collective identity and ownership.

Division of Lombok Island Administration Area:

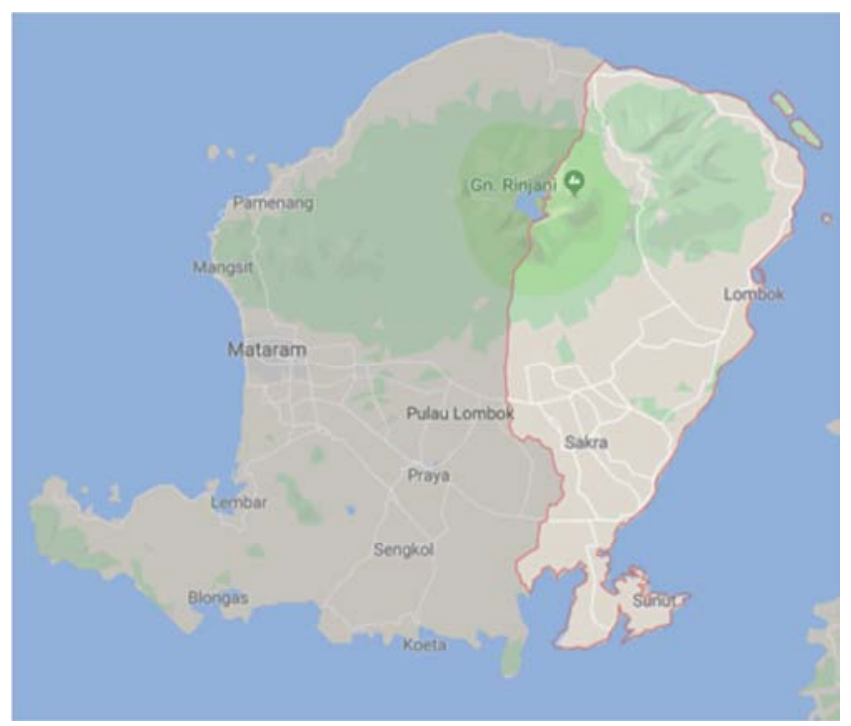

Figure 18. Administrative areas of East Lombok.

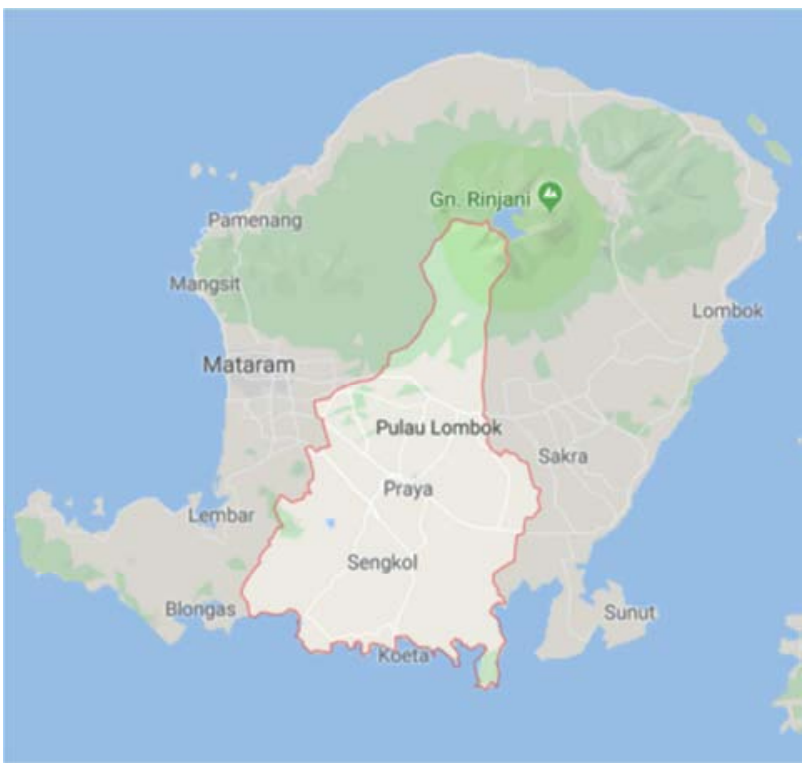

Figure 19. Administrative areas of Central Lombok.

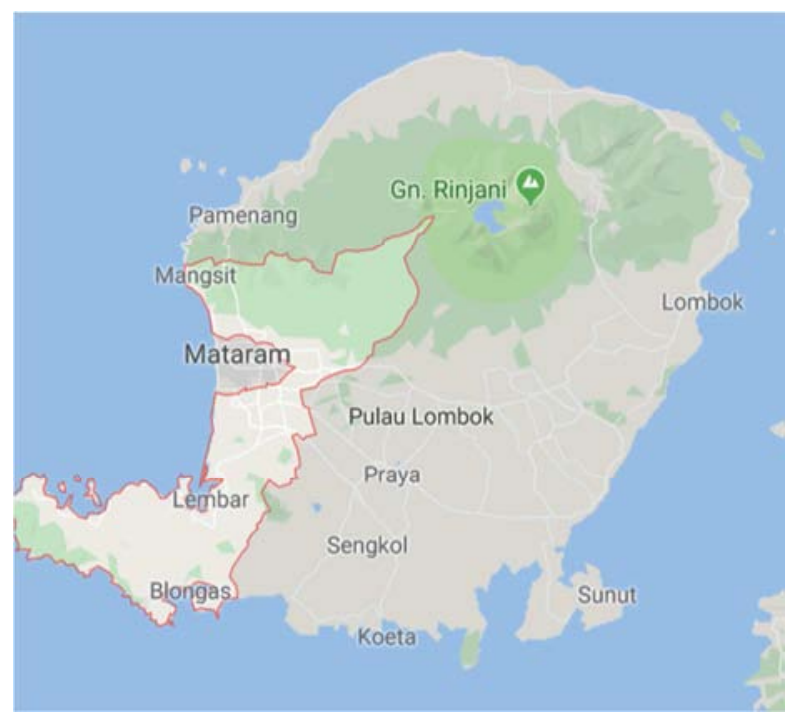

Figure 20. Administrative areas of West Lombok.

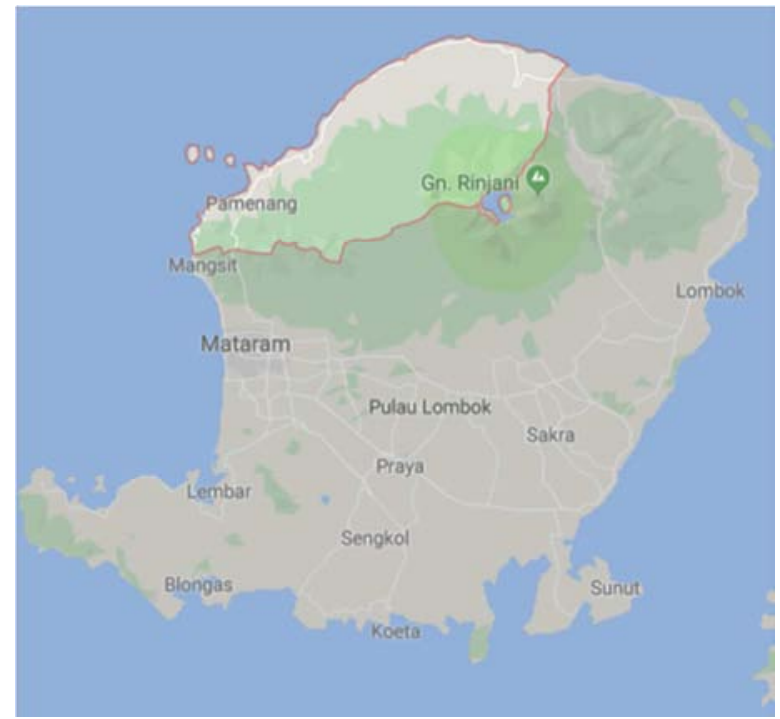

Figure 21. Administrative areas of North Lombok. 


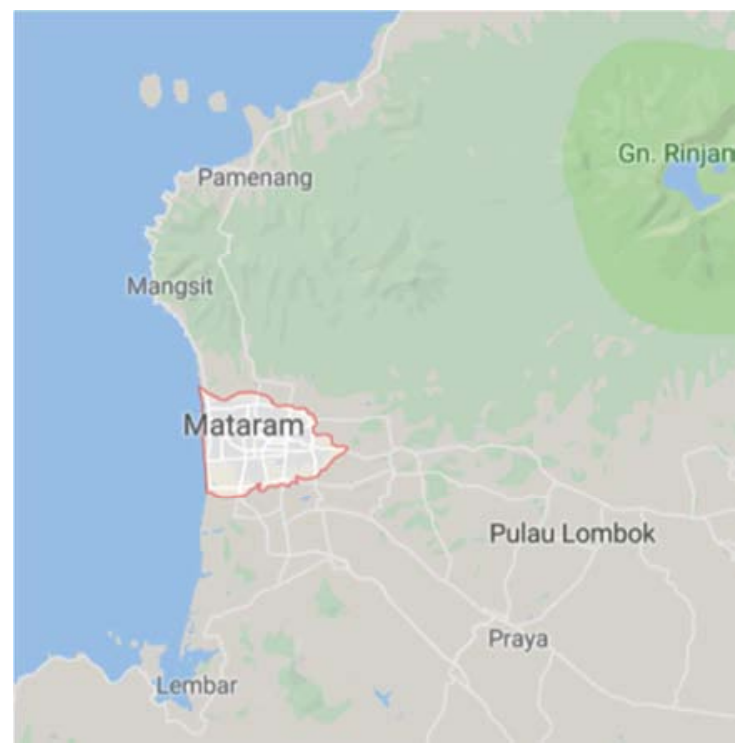

Figure 22. Administrative areas of Mataram City.

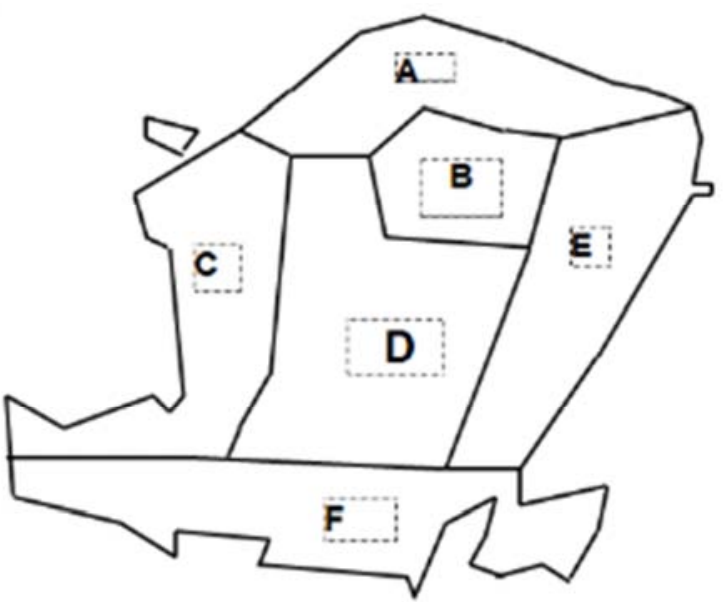

Figure 23. Division of "Paer" Regions: Paer Bat (west Paer), Paer Daye (North Paer), Paer Tengak (Central Paer), Paer Lauq (South Paer), Paer Timuk (East Paer) and Big Paer (Paer Beleq).

\section{Results}

This research stage analyzes the mosques from 22 different locations in the region that represent the problem and illustrates the symbolic meaning in the cultural, social and economic context of the Sasak community on the island of Lombok

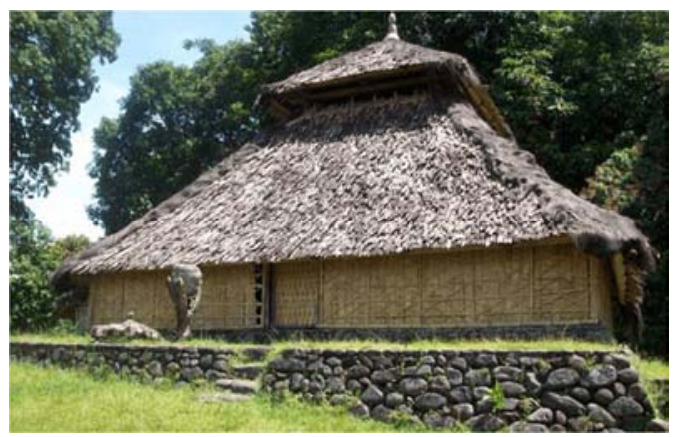

Figure 24. Ancient Mosque in the village of Bayan, North Lombok Regency.

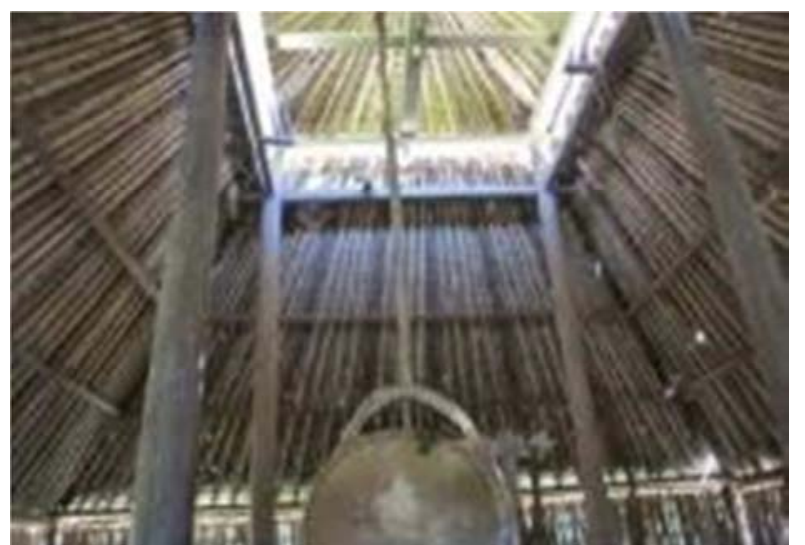

Figure 25. Ancient Mosque interior in the village of Bayan, North Lombok Regency.

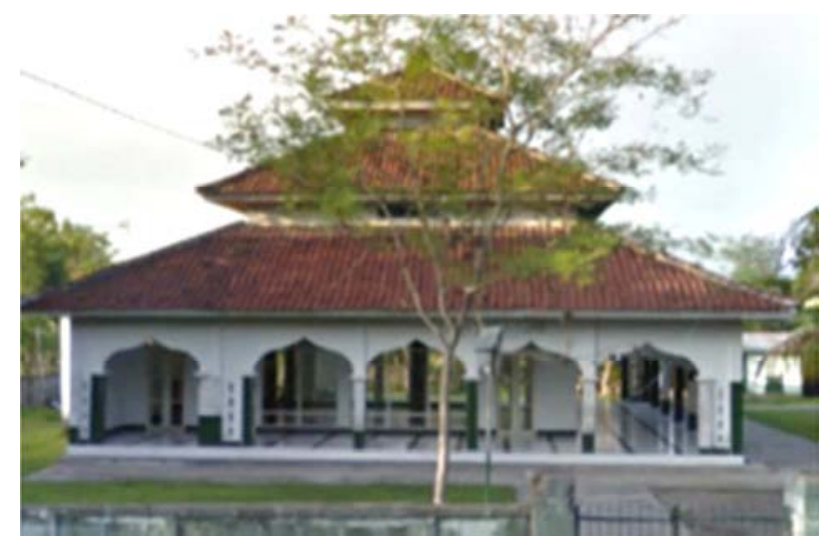

Figure 26. Al Mujahidin Mosque, Simbar sub-village, Bayan village, with a model of stacking roof 3 of tile.

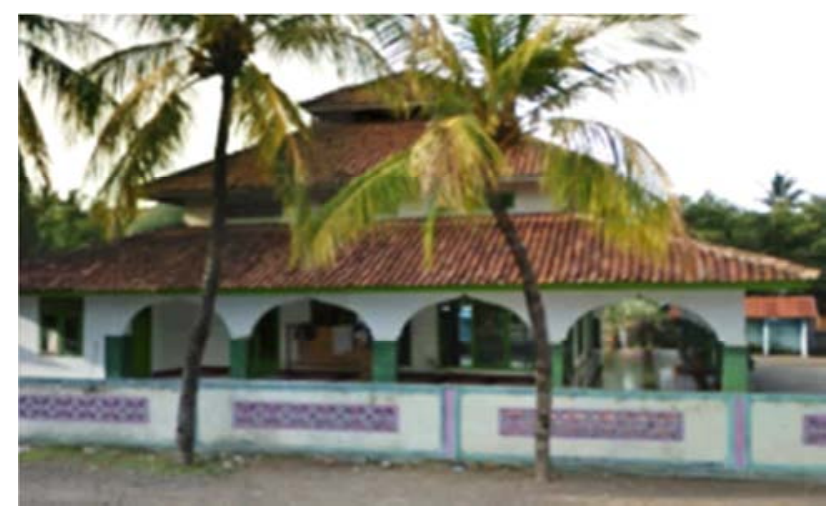

Figure 27. Nurul Hidayah Mosque Belanting village Bayan sub-district, also with a three-tiered roof model.

The Bayan Ancient Mosque was the first to be built in Lombok in the 1300s at the beginning of the entry of Islam into Lombok. Located on the hill and in the yard lies the tomb of some people who used to maybe who built this mosque. The roof is made of bamboo which is cut in half and the walls are also woven bamboo being a model for the shape of the surrounding mosque in North Lombok. This ancient mosque because of its small size and still with old building material which is preserved for its authenticity is not used anymore except on certain days by some elders of the indigenous people Bayan. 


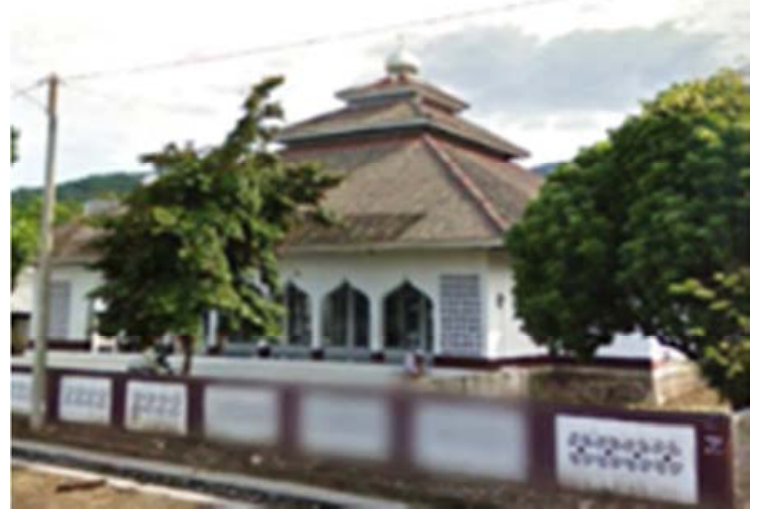

Figure 28. Qoidul Iman Mosque, Sembalun Lawang with a three-tiered roof model.

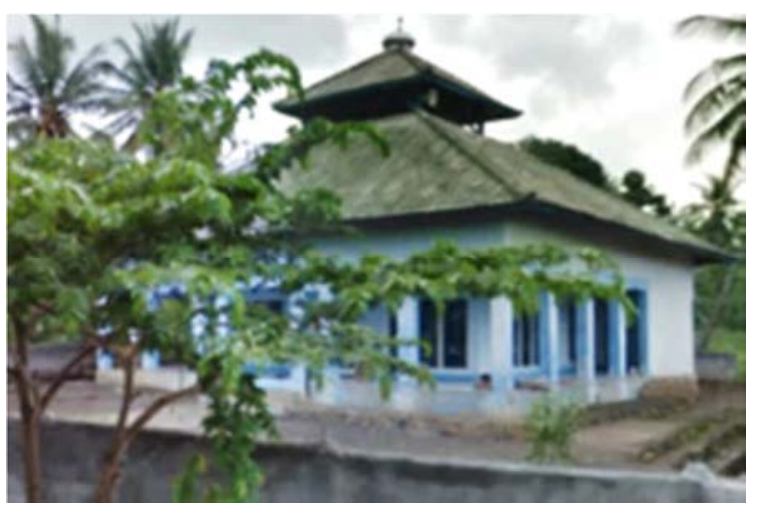

Figure 29. Nurul Iman Mosque, Obel-Obel village kec. Sambelia, tile roofs stacked in two.

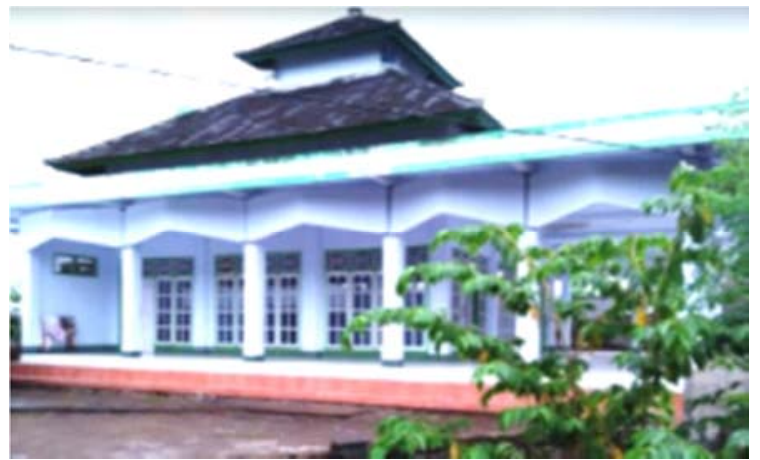

Figure 30. Islahul Ummah Mosque, Sembaro sub-village, Bayan sub-district.

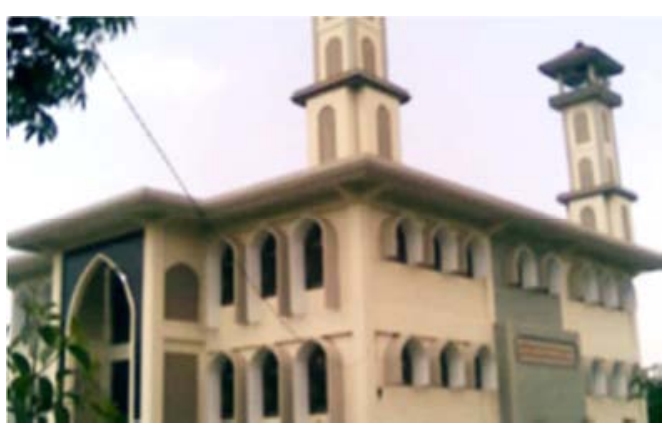

Figure 31. Nurul Ikhlas Mosque, Bayan village.

These four mosques are in the North Lombok area which was built around 1960 with tile roofs, without towers and up to now in 2019 some of the mosques that have not been adapted have become domed roofs, because the Bayan people are known to still hold their traditions and customs for generations. The location of the 4 mosques is adjacent to the Ancient Bayan mosque which was first built in Lombok and the roof is a model for the surrounding mosque in North Lombok.

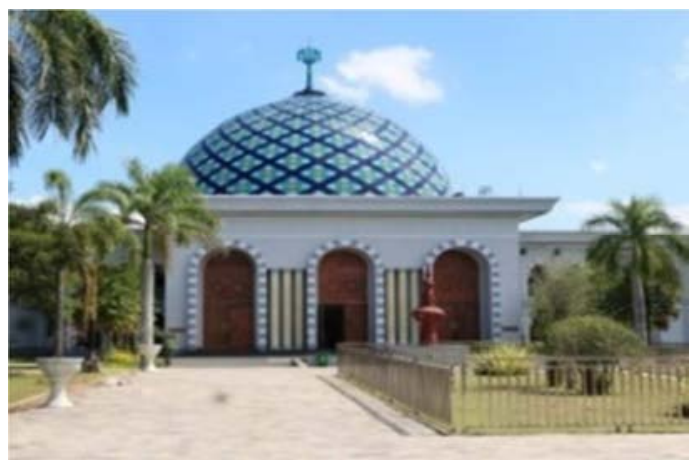

Figure 32. The "tebolak" dome in At Taqwa Great Mosque in Praya, Central Lombok.

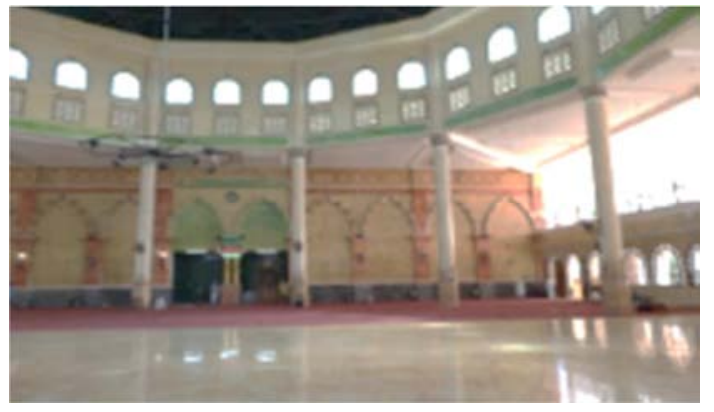

Figure 33. The interior of the At Taqwa mosque in Praya, Central Lombok.

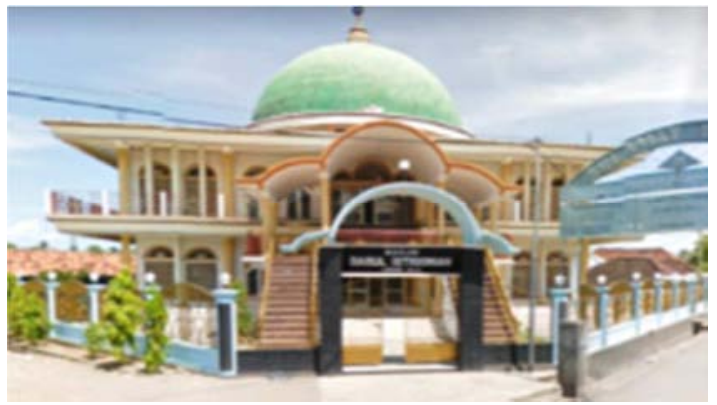

Figure 34. Darul Istiqomah Mosque, Tanak Song hamlet, Batukliang village.

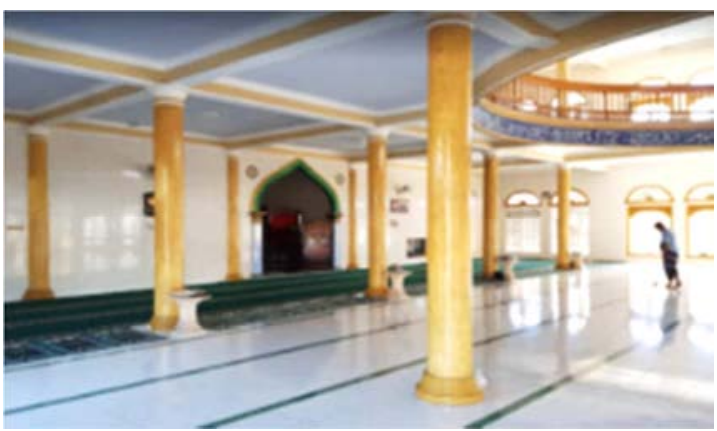

Figure 35. Interior of the Darul Istiqomah Mosque, Tanak Song sub-village, Batukliang village The shape of the mihrab is curved like a dome roof. 


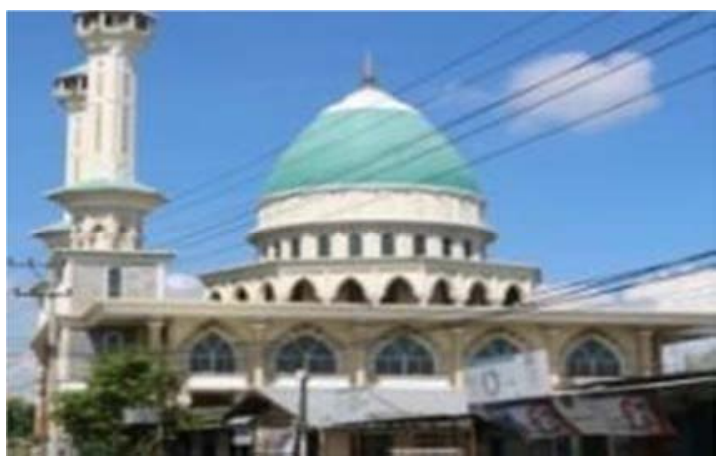

Figure 36. The tebolak dome in Darul Hidayah Mosque in Cermen hamlet, sub-district Cakranegara.

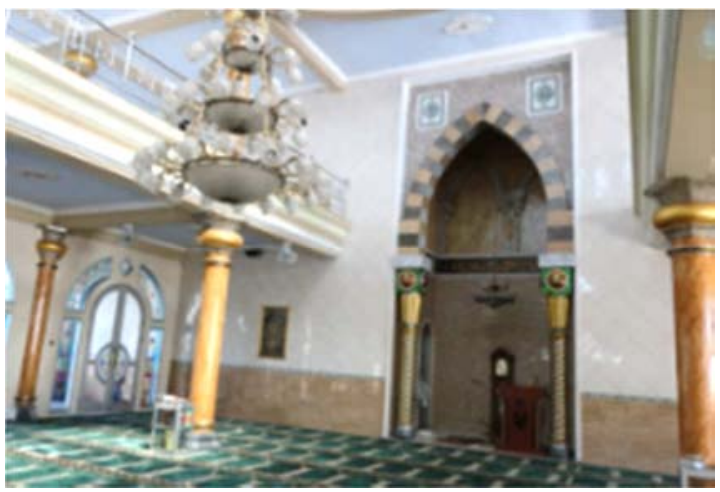

Figure 37. The Interior Darul Hidayah Mosque in Cermen hamlet, subdictrict Cakranegara.

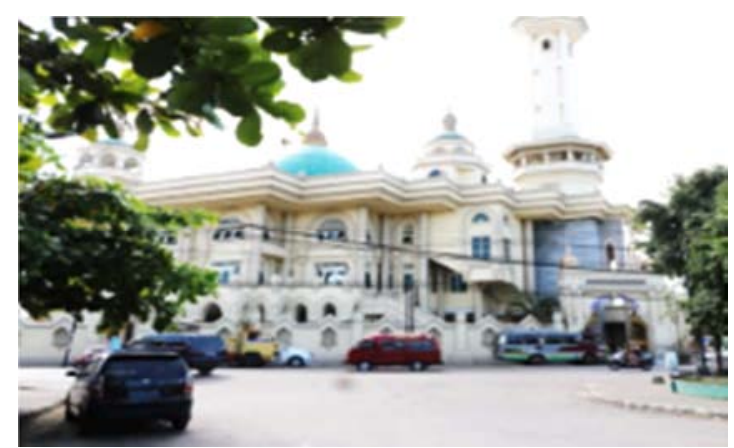

Figure 38. The Great Mosque Al Akbar Kumbung village sub-district Masbagik, East Lombok Regency.

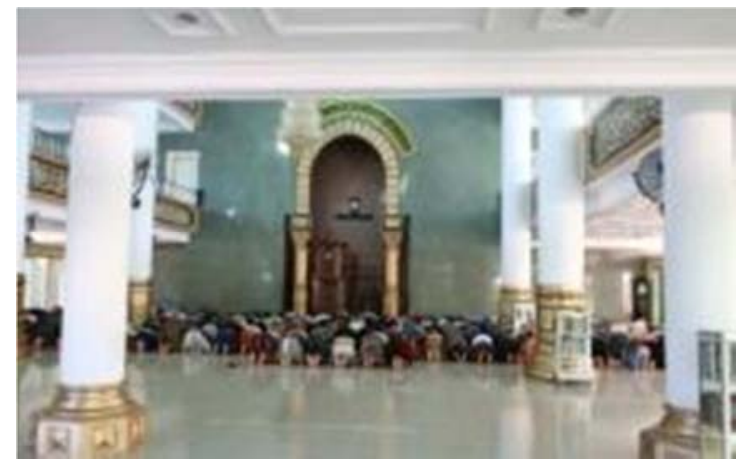

Figure 39. The interior with the foreground of the mihrab of the Great Mosque of Al Akbar Kumbung village sub-district Masbagik, East Lombok Regency.

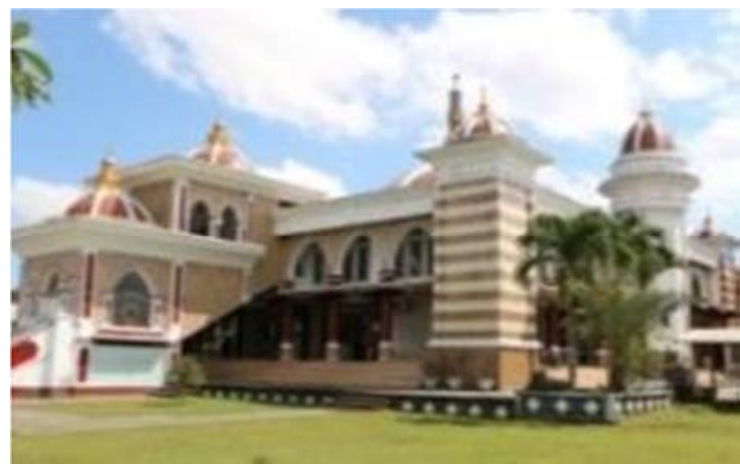

Figure 40. Side view of Darussalam Mosque, Kopang Village.

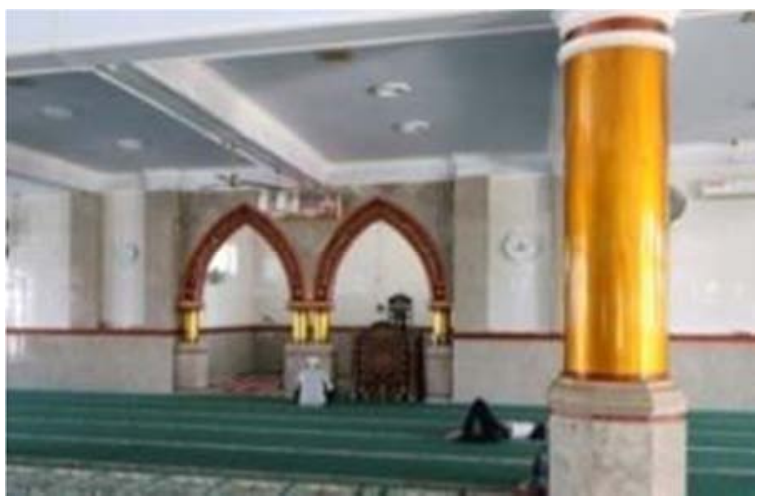

Figure 41. Interior of the Darussalam Mosque in Kopang Village shows a mihrab with two arches.

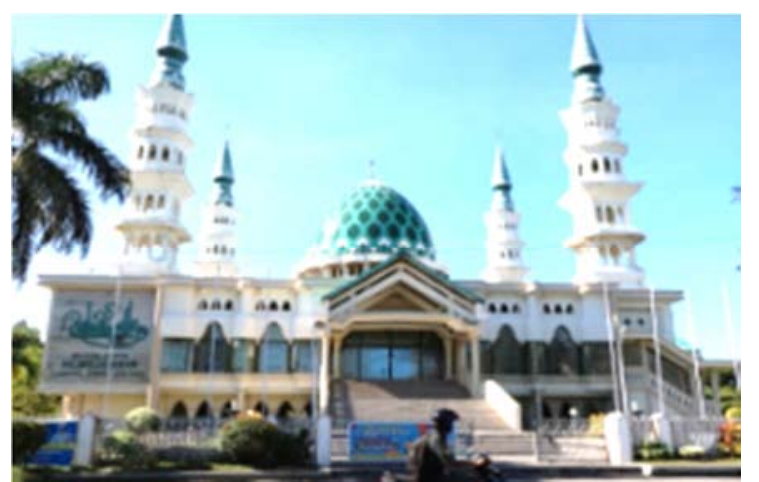

Figure 42. Front view of Al Mujahidin Mosque Selong, East Lombok Regency.

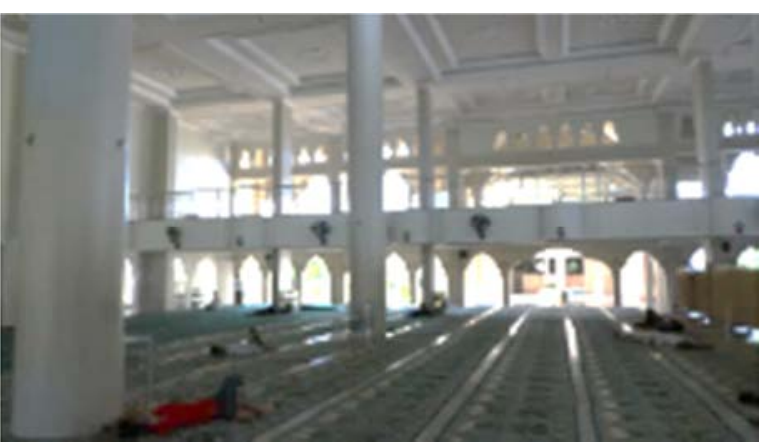

Figure 43. Interior of Al Mujahidin Mosque, Selong, East Lombok Regency. Arched walls and mihrab of Al Mujahidin Mosque in Selong are redundancy of the curved outline of the dome model on the roof. 




Figure 44. The exterior of the Kerangkeng hamlet mosque in Banyumulek village, twin towers with a height of $65 \mathrm{~m}$ and a dome-shaped "tebolak".



Figure 45. The mihrab of the Kerangkeng hamlet mosque in Banyumulek village.

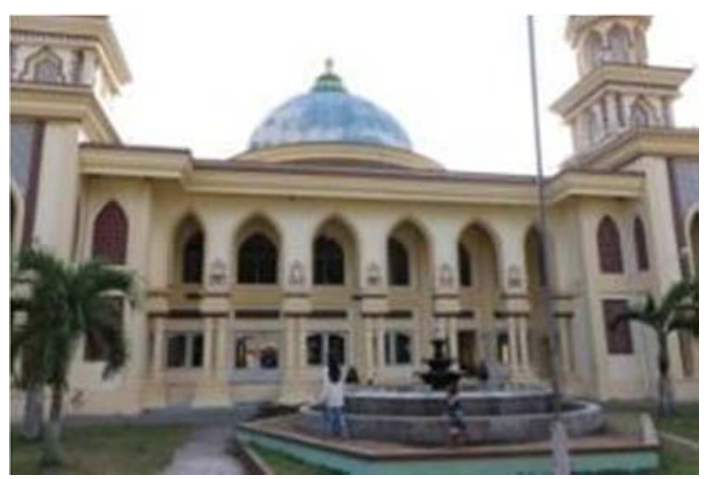

Figure 46. Darussalam Mosque, Lendang Nangka Village, Masbagik District, East Lombok.

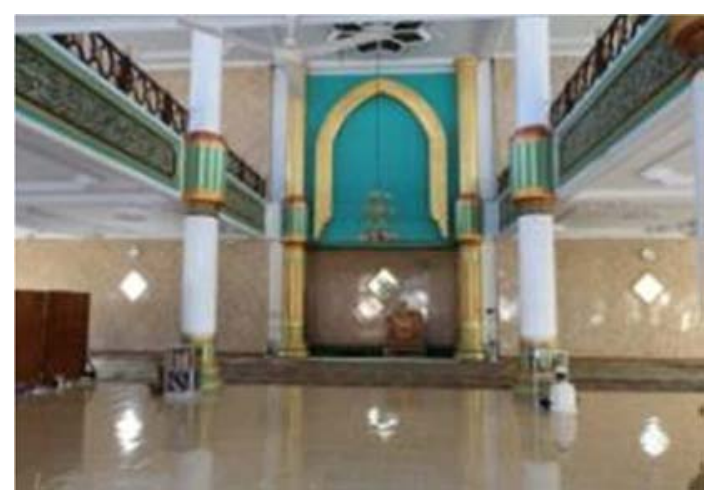

Figure 47. Mihrab of Darussalam Mosque, Lendang Nangka Village, Masbagik District, East Lombok.

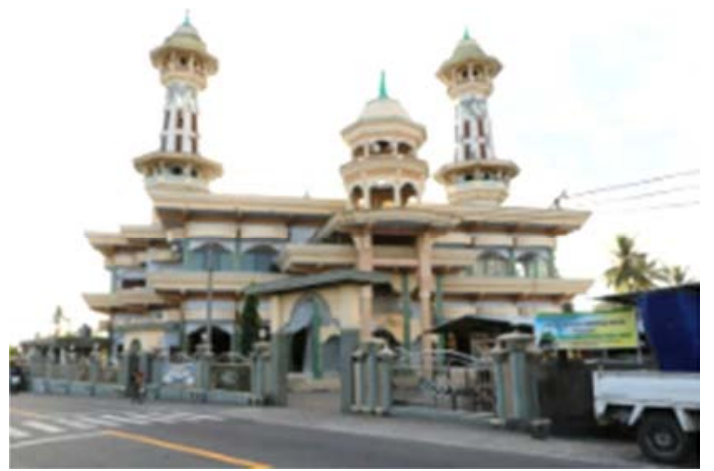

Figure 48. Nurul Jihad Mosque in Aik Darek hamlet in the village of Pancordao, Batukliang sub district, Central Lombok Regency.

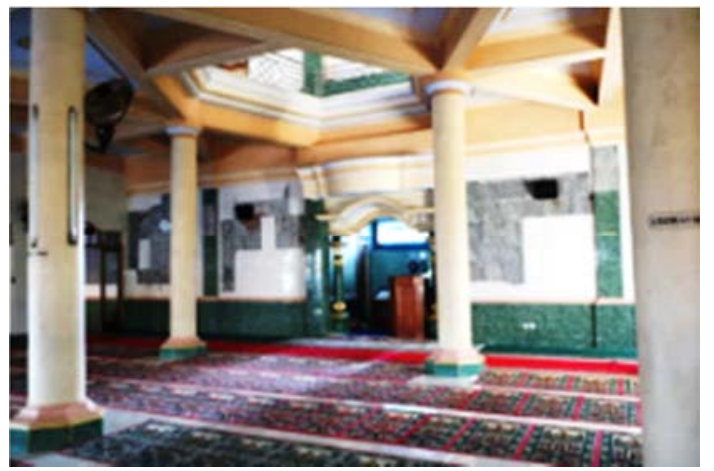

Figure 49. Interior of Nurul Jihad Mosque in Aik Darek hamlet in the village of Pancordao, Batukliang sub district, Central Lombok Regency.

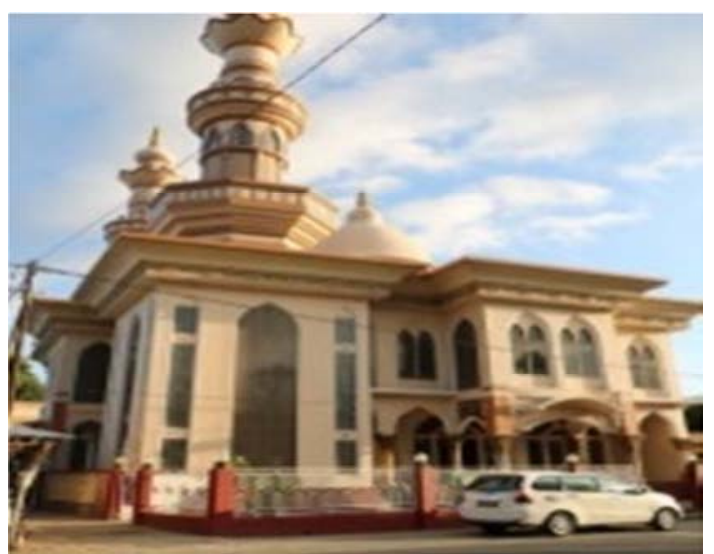

Figure 50. Al Hidayah Mosque Penjangke village, Central Lombok and Mihrab Al Hidayah Mosque Penjangke village, Central Lombok.

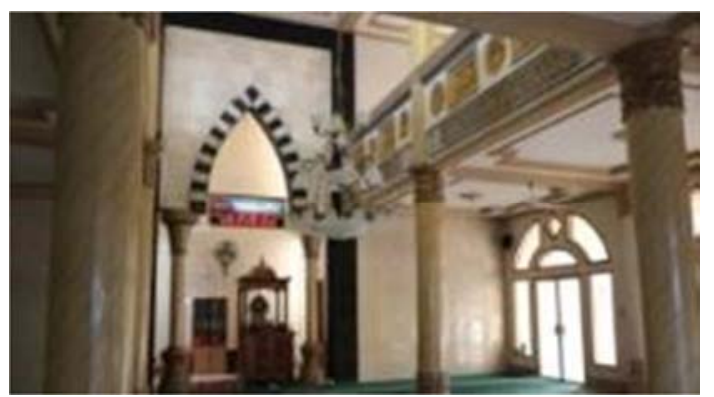

Figure 51. Interior of Al Hidayah Mosque in Penjangke village, Central Lombok. The shape of the mihrab is curved like a dome roof. 


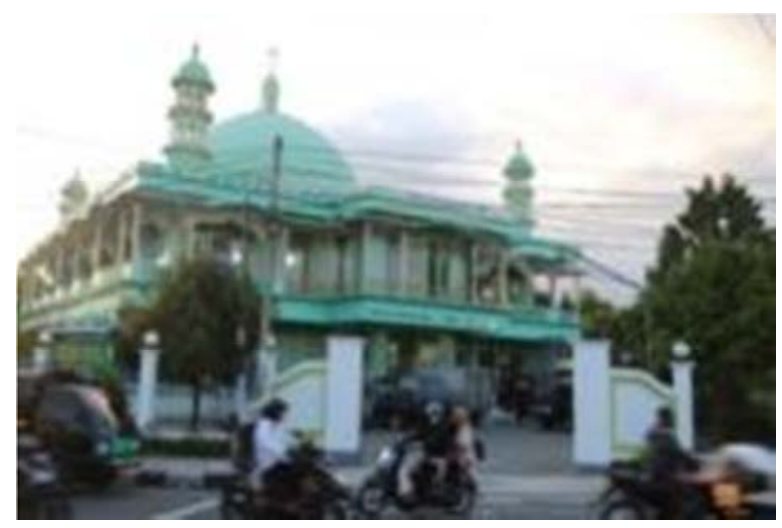

Figure 52. Nurul Jihad mosque in Narmada village, West Lombok Regency.

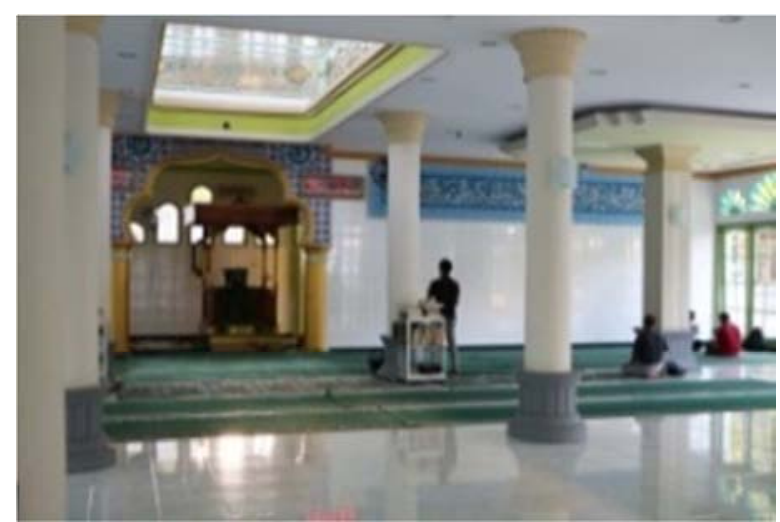

Figure 53. Interior of Nurul Jihad mosque in Narmada village, West Lombok Regency.

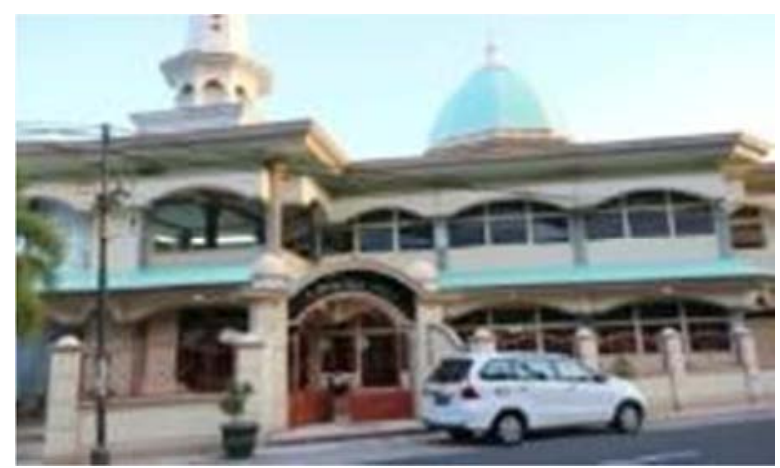

Figure 54. Syamsul Huda Mosque, Lingsar village, West Lombok Regency.

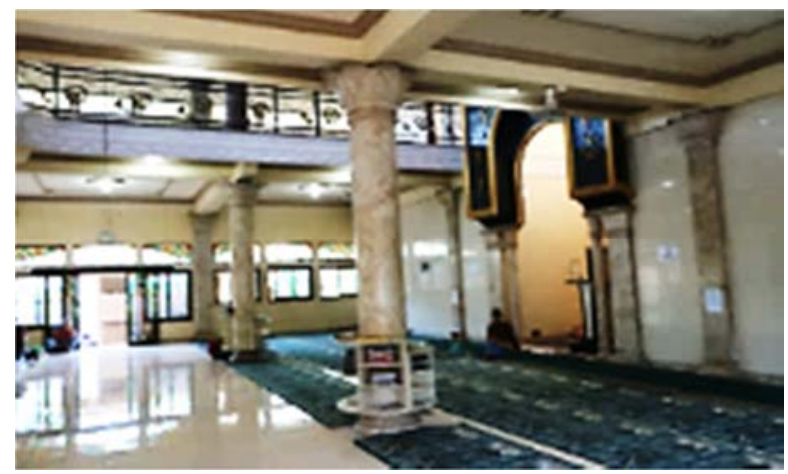

Figure 55. Interior of Syamsul Huda Mosque, Lingsar village, West Lombok Regency.

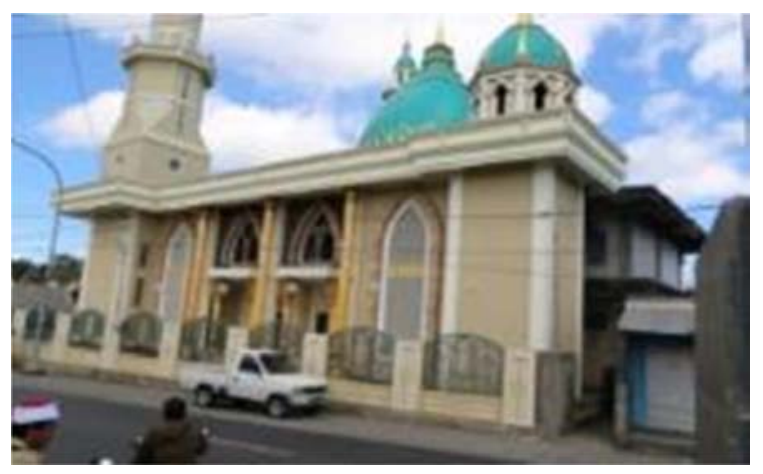

Figure 56. Exterior of the Al Ijtihad mosque in the village of Montong Gamang, Central Lombok Regency.



Figure 57. Interior of the Al Ijtihad mosque in the village of Montong Gamang, Central Lombok Regency.

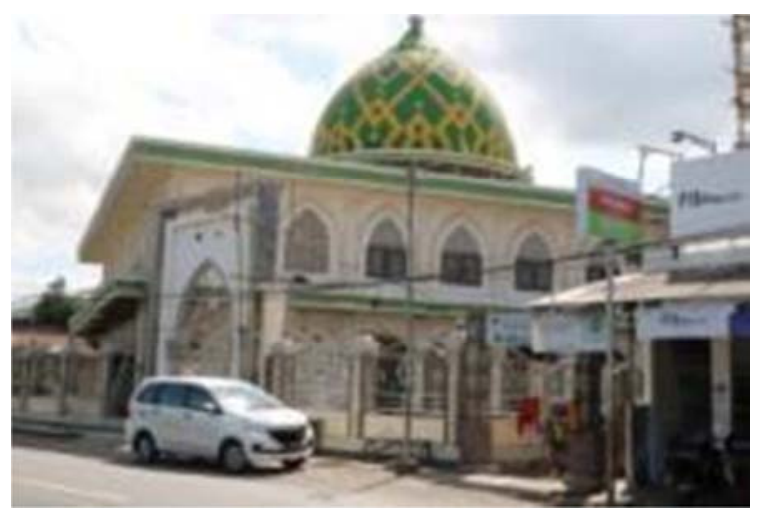

Figure 58. Exterior of the Islahul Muslimin mosque in Sikur village, East Lombok Regency.

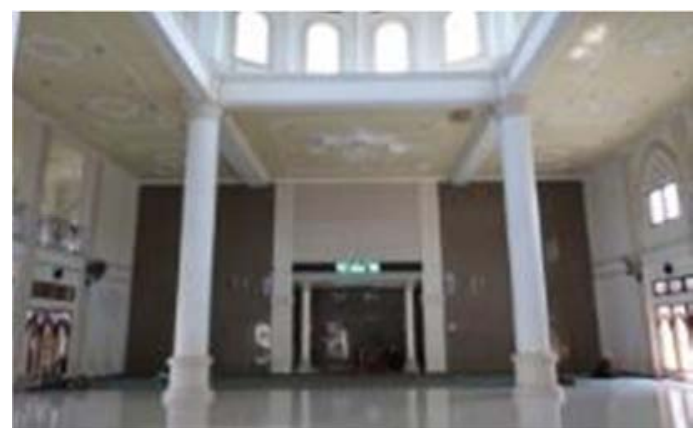

Figure 59. Mihrab of the Islahul Muslimin mosque in Sikur village, East Lombok Regency. 


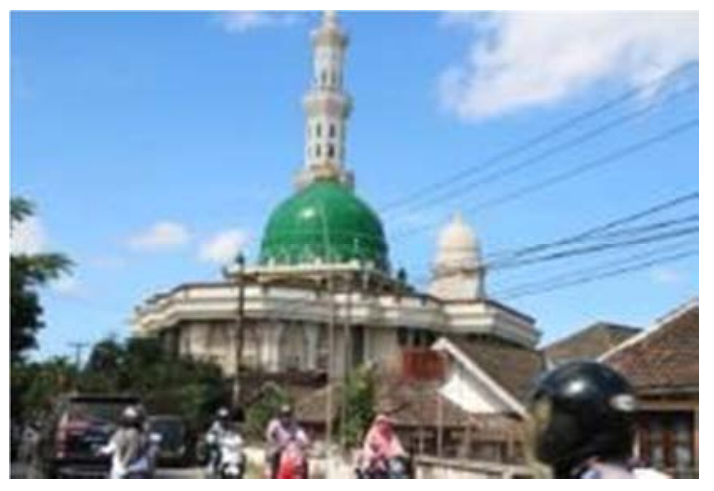

Figure 60. Raudatul Aitam mosque in the village of Bilasundung, Masbagik sub-district, East Lombok.

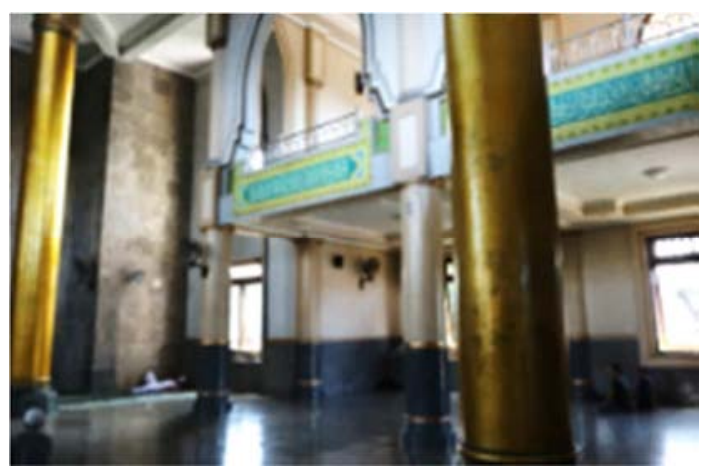

Figure 61. Interior of Raudatul Aitam mosque in the village of Bilasundung, Masbagik sub-district, East Lombok.

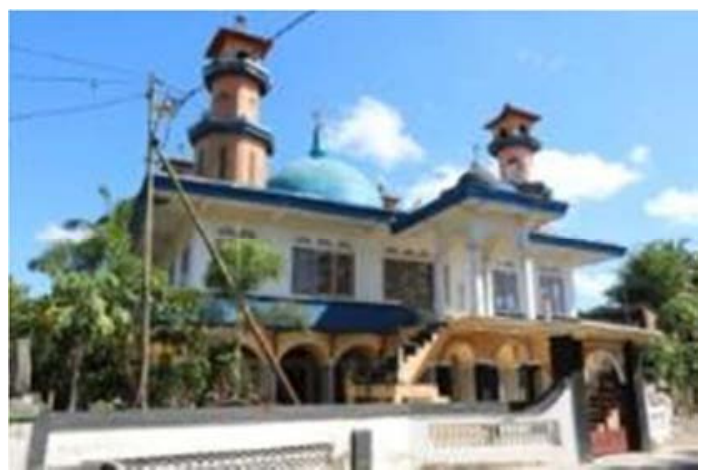

Figure 62. Exterior of the Nurul Hidayah mosque in Batutulis village Jonggat sub-district, central Lombok district.

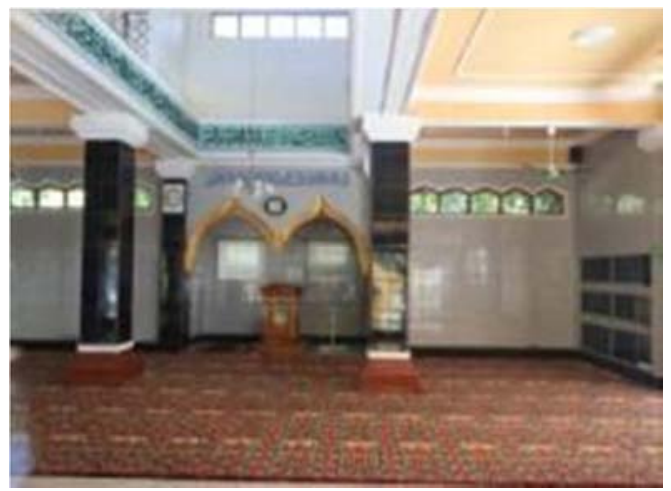

Figure 63. Mihrab of the Nurul Hidayah mosque in Batutulis village Jonggat sub-district, central Lombok district. The shape of the mihrab is curved like a dome roof.

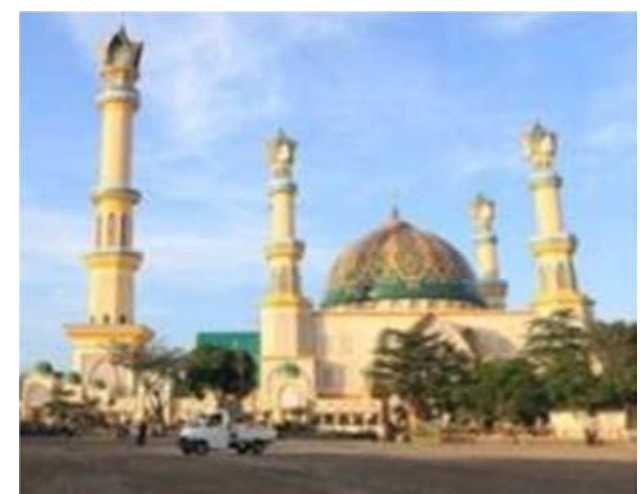

Figure 64. Side view of the Hubbul Wathon Islamic Center Mataram mosque. It has 5 towers with one dome-shaped dome.

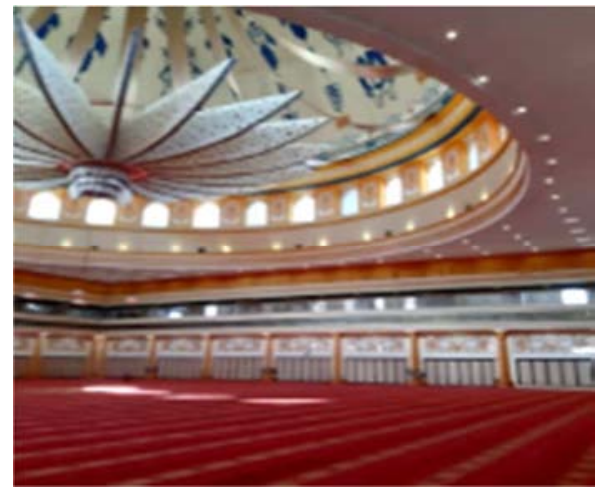

Figure 65. Ornaments under the dome roof with a motif common to "tebolak" or traditional Sasak food hoods.

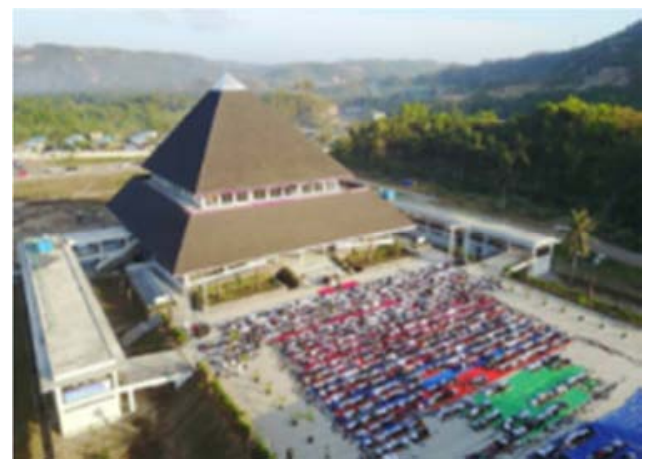

Figure 66. Nurul Bilad Mosque at Mandalika Special Economic Zone.



Figure 67. Nurul Bilad Mosque as the center of orientation of the Mandalika region, with the shape of the limasan roof as if to repeat the form of many rock hills around the Mandalika beach. 
The Hubbul Wathon Islamic Center Mataram mosque was built on 6.7 hectares of land with 4 towers as high as $66 \mathrm{~m} 1$ tower as high as $99 \mathrm{~m}$ representing the numbers of the names of Allah / Asmaul Husna, and the dome-shaped "tebolak" roof dome or a giant size dining hood with the top of the dome shaped hilal or crescent moon. The highest tower contains an elevator to take visitors up to see the view towards the city of Mataram. Nurul Bilad Mosque which means "Light for the Nation", is expected to be a torch to illuminate all aspects of life in the Mandalika Special Economic area. Built on an area of 8 hectares, only 500 meters from the beach of Mandalika Kuta Lombok, before building other functions for tourism. Because it will be surrounded by 5-star hotel buildings, the "Nurul Bilad" mosque was built as an artifact of a large and modern mosque to suit the hotel and residential buildings.

Both of these large mosques are ineun paer or mothers of waiting space in two different regions, the Hubbul Wathon mosque in the city of Mataram as the capital of West Nusa Tenggara Province, and the Nurul Bilad mosque in the tourist area of Kuta Mandalika. The architecture of the two mosques has a different design approach.

\section{Symbolic Adaptation of Mosques in Cultural, Social and Economic Contexts}

The change of belief and worldview from the Sasak Lebung or old Sasak which is mythic-dynamism to the mythic-religious Sasak goes to adapt the culture and patterns of interaction in the local social space, so that even though it undergoes a transformation of meaning and orientation, in some cases such as artifacts and artistry it does not experience changes, only adjustments so as not to conflict with Islamic teachings. While the values in social life that are in accordance with what is taught by Islam then experience a strengthening of meaning. Like the values of togetherness in the Sasak tradition are strengthened by displaying the congregation patterns in worship and practices in other social lives. Then the value of kinship and togetherness is strengthened by the implementation of the concept of social space that puts togetherness before personal ownership [13].

The concept of mother of place before Islam that leads to natural objects such as large trees then underneath formed social transaction activities in the form of 'temporary market' or tenten market at a certain time, then became "mother of waiting space" on natural objects springs large or aik kembulan formed a 'sedahan aik' social system that regulates the use of water fairly and equitably. After Islam became the dominant religion and belief in life, the concept of mother of waiting space or Ineun Paer experienced adaptation with her object shifting to the building of the mosque and the social system of life underwent an orientation at the mosque.

The concept of mother of waiting space or Ineun Paer then encourages kinship life and a strong social system among fellow villagers oriented to the village mosque mosque artifacts, also at the village level too. The kinship social system in the hamlet regards all hamlet residents as a large family so that the territorial inter-dwelling houses in the hamlet are not limited by yard fences. The daily life of the Sasak traditional community takes place in groups based on the family bond of 'sorohan' in the lowest level of paer called 'paer bale langgak', both as single families and multiple families. Various cultural events related to the life cycle and various traditional events carried out by Sasak people will always be related to the use of paer bale langgak space. The arrangement of the Sasak community's residential space after becoming Islamic appears to be influenced by the determination of the direction of the roof of the building which is oriented to the mosque, because the face of the building will always face the village road that is daily passed by the inhabitants of the cluster bale langgak to go to the mosque so that buildings for a highlight are made in a line and lead go directly to the mosque, or lead to the nearest road to the mosque. In the implementation of various rituals related to life cycle, marriage and religion shows a sequential use of space that starts from the cluster bale langgak leading to the mosque so that there is a hierarchy of space based on the position of the cluster bale langgak and mosque.

The strong kinship at the level of extended family called sorohan and between villagers is not only shown by the physical connectedness of each bale langgak building and yard, also shown when dealing with people from outside the village that is seen by the behavior of receiving and entertaining guests. The arrival of guests from outside the village in one household or cluster bale langgak will also be accepted by other bale langgak spontaneously sending dishes that are available at home that day. Even guests for one family can be accepted and entertained in another family's home, solely for consideration of comfort that can be given to these guests. Every guest who is received a visit to a family at the cluster bale langgak means also accepted and may be entertained by another cluster bale langgak.

Seeing Sasak people whose dwelling is oriented towards mosque activities, then building Sasak communities in villages must be mosque-based. The mosque is also a place to build social and economic life because it is in line with its function as an activity center orientation. The mosque-based development, of course, is unique to the Islamic worldview as the glue of the Sasak traditional community. The paradigm is the process of development is actually a process that makes humans as the beginning and end of its activities, and what is built is not only the physical settlement of villages and villages, but the people who live there.

The Sasak people who spend more time in daily activities at the mosque place great importance on religiosity in their home environment. The cluster pattern in the residential space of hamlets and villages in Lombok which is concentrated around the mosque and not on the edge of the highway can indicate that the community is not too interested in using the road as a path for economic activity, more concerned with the presence around the mosque for ease of worship. This pattern is their choice even though they also 
understand that managed agricultural products must be sold through the road distribution channel. If traditions that adhere to the Islamic concept become identical as a way of life in the Sasak community in Lombok, the meaning of development does not have to be interpreted as the progress or change of a physical condition of the residential environment which is the goal, but the physical improvement of humans / physically and consciousness / inner, where in the improvement the teachings are oriented to the mosque and the values of revelation must be used as a reference and guide the Sasak community development concept.

The nature of man for Islam and its position in the world of existence does not depend on the physical and genetic elements but on the spiritual and behavioral elements that are guided by religiosity, namely ahlaq, while the body or physical element is only a vehicle for the spirit when living life. In terms of physical and genetic differences between humans from one another is very small but the spiritual differences as controlling behavior between them make humans in Islamic concepts can be different like the earth and sky, namely between believers or mukmin and infidels or kafir (= do not accept the teachings of God).

The transformation of the mosque as the center of village spatial orientation is not enough to just carry out the function of worship. But it must also be the center of the transformation of the social and economic life of the community, perhaps through the development of cooperatives as part of the mosque unit activities. Cooperatives whose management is based on agricultural processes and products managed by village communities through their mosques will be the drivers of change. The life of the Sasak community in the village must be encouraged to continuously become better and prosperous, so that they can improve the quality of worship that is not only individual but also social worship. For the approach to success, it can be used the real insight of Islam which also attaches greater importance to the value of worship together and activities to promote social life when compared to individual worship.

The cooperative business centered on the mosque will provide encouragement to improve the socio-economic life together without involving external parties in the village, while maintaining the structure of indigenous peoples and orientation spaces that strengthen the village cluster pattern. In other areas where the village space is oriented towards economic life on the highway as a distribution crossing, it is always marked by the presence of shop houses that line up along the road. Shop houses that are almost uniform and dominated by certain retail Mart industry brands make the boundaries between villages in several villages become connected because their presence will always be followed by other shop businesses.

Almost all villages in other regions when viewed from satellite photos depict linear and elongated patterns according to the road lane, indicating community life oriented towards economic activity. The village-dea orientation pattern in Lombok has a peculiarity that is not found in other regions, because of the daily activities of the people farming and in the mosque. Mosques in Lombok villages are the center of life, so the cluster of houses surrounding the mosque becomes the spatial pattern of all villages in Lombok. Madrasa or Islamic-based education and education adjacent to the location of the mosque in the villages, held by the village community only to teach memorization of the Qur'an. The cluster pattern of village space surrounded by rice fields and centered on the mosque indicates the kinship of the village. The pattern of social life will also be dominated by the kinship, so it is unfortunate if the pattern of kinship and life orientation in the activities in this mosque is damaged by the expansion of the retail industry which makes the outlet at the mouth of the road and then followed by other shop houses that close the village verges. If the presence of retail stores is not regulated and restricted it will damage the Sasak village spatial arrangement which is more centered on the mosque as exemplified by the life of the Prophet Muhammad's era. The Paer space culture in the life of the Sasak Lombok community should be maintained and strengthened by the support of the local government not to allow the retail industry to influence the villages.

The social space of the Sasak community is not an abstract substance but is a concrete living space of the human environment called adat village, created in the context of a traditional Sasak community [14]. This social space is a product of the transformation of nature through a process of thought and work which includes boundaries in the form of villages, hamlets, rivers, lakes, mountains, beaches, forests and others. The Sasak community's social space is also a staging of social relations and is engineered by the population in various degrees of intervention / change. Starting from the smallest modification of the cluster bale langgak, madrasas, mosques, which have little impact on the environment; to the modification of medium-sized banjars, hamlets, villages and areas whose engineering will inevitably change the environmental layout.

Philosophically, development in terms of social space is formulated as an endless "community movement", as long as the process of living in the community concerned feels more just, more humane, and more acceptable to its citizens. Promoting community movements in development in terms of social and cultural space has the opportunity to revive the spirit and practice of togetherness among Lombok villagers who in fact they had known in the effort to live together together, including paddy water management systems such as Sedahan Aik.

It is fitting that the development of the tourist area planned by the local government is treated as a local community movement, involving residents who will be affected by the construction of tourism infrastructure, respected humanitarian people's dignity. Development in terms of social and cultural space will require the participation of villagers in decision making, especially those that personally bear the impact of decisions. So, there is a kind of interaction between local citizen participation and strategies aimed at meeting the basic needs of citizens in general. In so doing building a villager is "humanizing a villager". 
Development in terms of social space is also a staging of social relations and is engineered by the population in various degrees of intervention / change, such as the example of the development of the Gili Trawangan tourist area which becomes a participatory development along with participatory democracy. Meaning, in the midst of the practice of indirect democracy there is still a chance of life for the practice of continuous democracy among the people. The people are asked to vote, every time they make decisions about development projects in their residential area. Thus, it will even arise and develop simultaneously and complement each other between political democracy, economic democracy and social democracy.

If applied consistently, the construction of such a model will spontaneously develop various related cultures:

communication culture, economic culture, legal culture, artistic culture, even scientific culture. Over time social space can become a learning community, which is the ideal basis for the formation of civil society. The concept of development in the village needs to also understand the typical problems faced by residents in the coastal area of Lombok that have quite a large population. 'Waiting space' on the beach called paer pesisi almost along the coast of Lombok is disrupted because in addition to the area being a location of hospitality and tourism activities, the Paer space will also become an area that is no longer known to traditional communities, so the concept of Paer tradition regarding space in coastal areas are no longer relevant to them. Almost all of the "paer pesisi" space on the coast of Lombok because of its beauty have the potential to undergo a transformation of function into a tourist area. Thirty small islands (gili) around the coast of Lombok which are all beautiful are now 13 gili already filled with tourist structures. Then like the history of Bali tourism where the mountain cliffs in Ubud turned into a hotel area, then the slopes of Mount Rinjani like in the village of Sembalun will experience the same thing.

The right solution to the typical problems of coastal villages and their residents in Lombok is how they need to be involved in managing beach tourism, so that they are compensated in the economic aspects of their loss of 'changing' space Almost all coastal areas in Lombok have distinctive beauty and have the potential to become a tourist destination if managed properly. In Gili Terawangan it is interesting to note, namely how ineun paer in the gili is in the form of a mosque, its management institution or the Mosque Welfare Board then earns a steady income for the development of the mosque from renting diving equipment, diving, snorkeling, and tourist boats in the gili area so that it can build a mosque in another location that is bigger than the old mosque. Gili Terawangan has two mosques that are quite large and are used for the entire Gili community including tourists who are Muslim. All the community members of the two mosques work as tourism operators of the Gili tourism area are Cidomo drivers, boat drivers, food vendors, hotel employees, and security. Before the development of the Gili Terawangan tourism, the mosque congregants were fishermen who then transformed into tourism industry players because their land and house turned into expensive hotels.

\section{Symbolic Meaning of the Mosque and the Concept of the Sasak Cultural Space}

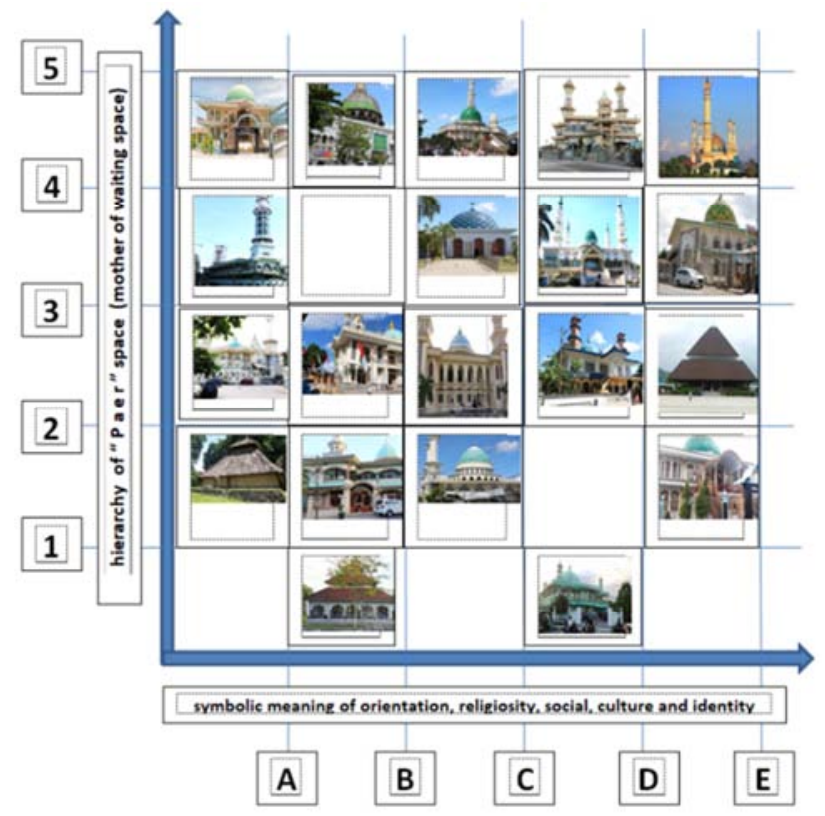

Figure 68. Matrix of Symbolic meaning of the mosque and the concept of the Sasak cultural space: 1. "Paer"/Mother of Waiting Space in Bale Langgak Cluster, 2. Hamlet Mosque, 3. Village Mosque, 4. Sub-district Mosque, 5. District Mosque, A. Symbolic meaning of orientation, B. Symbolic meaning of religiosity, C. Symbolik meaning of social interaction, D. Symbolic meaning of Sasak Culture, E. Symbolic meaning of Islamic Identity.

\section{Conclusion}

The mosque architecture in Lombok succeeded in declaring itself to be an identical Islamic Architecture and at the same time giving the characteristics of local cultural elements on the dome roof of the tebolak model. Can respond to the issue that in recent years the problem of cultural identity in contemporary architecture has become important for creating uniqueness and local identity in a competitive environment at the global level [15].

The mosque is the center of orientation of the space that binds the occupancy so that the value of the closeness to the mosque exceeds the value of access to the highway which in other regions is considered economically high. The position of the mosque becomes a "behavior setting" for the whole community and makes the dwelling room space and typical Lombok village clustered patterns. With its unique environment, some villages in Lombok have been able to attract attention for tourists, as an alternative to enjoying the beauty of the beach or mountain. The uniqueness of this village is that due to its traditional customs which are still preserved such as in Sade village, Ende village, Bayan 
village, Rembitan village, Segenter village. Some are due to being a special craft center such as pearl jewelry in Sekarbela village, pottery crafts in Banyumulek village, traditional weaving crafts in Sukarara village, ketak woven crafts in Rembiga village, cuklik furniture craft in Masbagik village. There are also those who have old preserved water parks that are still maintained in Narmada, Lingsar, Suranadi and Mayura. Then there is a village with a very typical pesantren life that attracts foreign tourists.

All the villages still have in common, namely having a mosque as the center of orientation and cluster housing centers. However, the cluster pattern of this dwelling if not maintained properly will soon be undermined by the presence of many retail shops of the modern economic system which are built in a row on the side of the road, thus covering and damaging the cluster system around the village mosque. Stores from each retail network will compete with each other with a bright display and choose a location alongside the road into the village, then it will be connected and continued by other shop houses so that the location of several adjacent village clusters will be connected, then the longer it will close from the front of the residential cluster pattern and mosque in the village. If it is left unattended, retail stores and other shophouses will grow and damage the order of the cluster pattern which is very typical for Lombok villages.

\section{References}

[1] Ehab Nasr Elden Ahmed Mohamed, 2014, "Islamic Architectural Character Between egitimacy and Disparity", Journal of Islamic Architecture Volume 3 Issue 1 June 2014. P-ISSN: 2086-2636 E-ISSN: 2356-4644. Journal Home Page: http://ejournal.uin- malang.ac.id/index.php/JIA

[2] Ben Stringer, 2017, "Architecture and Culture: A Villages and Globalization Issue" Taylor and Francis Journal Architecture and Culture.

[3] Omar S. Asfour, 2016, "Bridging the Gap Between the Past and the Present: a Reconsideration of Mosque Architectural Elements", Journal of Islamic Architecture, DOI $10.18860 /$ jia.v4i2.3559.

[4] Spahic Omer, 2012, "The Concepts of God, Man, and the
Environment in Islam: Implications for Islamic Architecture "Journal of Islamic Architecture, DOI 10.18860/jia.v2i1.1778

[5] R. Hillenbrand, 1994, "Islamic Architecture: Form, Function and Meaning”, Edinburgh: Edinburgh University Press.

[6] Sumaiya Ahmed, 2016 "Mosque Architecture or Architecture of Mosque: a New Notions of Bengal During the Muslim Rule" Journal of Islamic Architecture, DOI: 10.18860/jia.v4i1.3167.

[7] Putra, Nengah et al, "Cultural Awareness About Spaces in Society, in the NTB Region (A Study of the Adaptation Process)", Regional Cultural Inventory and Documentation Project, Prop NTB, Mataram, Ministry of Education and Culture, 1985/1986.

[8] The Village Empowerment, Population and Civil Registry Office of Nusa Tenggara Barat Province, 2017, "Daftar Mesjid Jamiq dan Mesjid Biasa di Propinsi NTB".

[9] Ayat Ali Yassin, Nangkula Utaberta, 2012, "Architecture in the Islamic Civilization: Muslim Building or Islamic Architecture", Journal of Islamic Architecture, Volume 3, Number 2, 1 July 2012, DOI: https://doi.org/10.1386/ijia.7.2.229_2

[10] Jonathan M Bloom, Sheila Blair, 2009, "The Grove Encyclopedia of Islamic Art and Architecture Volume 2".

[11] Keppel Archibald Cameron Creswell, 2005, "Thematic Encyclopedia of the Islamic World 4: Thought and Civilization".

[12] Becker, Elisabeth, 2019 "Reconstructing the Muslim Self in Diaspora: Socio-Spatial Practices in Urban European Mosques"International Journal of Islamic Architecture, Volume 8, Number 2, 1 July 2019, pp. 389-414 (26) Publisher: Intellect DOI: https://doi.org/10.1386/ijia.8.2.389_1.

[13] Syahdan, 2000, "Code-Switching in the Speech of Elite Sasaks", in Peter K Austin (ed), Sasak: Working Papers in Sasak, vol. 2, Department of Linguistics and Applied Linguistics, The University of Melbourne.

[14] Lalu Lukman, 2006, "Sasak Customary Cultural Arrangements in Lombok", NTB Mataram State Museum.

[15] Yasser Mahgoub, “Architecture and the expression of cultural identity in Kuwait" International Journal of Architecture and Culture, Pages 165-182 | Published online: 16 May 2007 https://doi.org/10.1080/13602360701363486. 